\title{
CEO Compensation and Real Estate Prices: Pay for Luck or Pay for Action?*
}

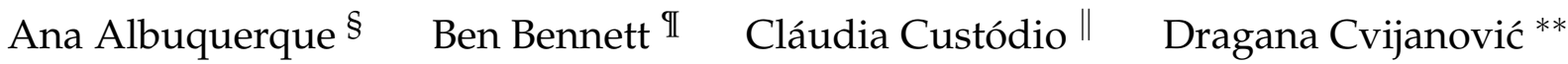

January 4, 2022

Accepted at the Review of Accounting Studies

\begin{abstract}
This paper uses variation in real estate prices to study CEO pay for luck. We distinguish between pay for luck and pay for responding to luck (action) by exploiting US GAAP accounting rules, which mandate that real estate used in the firm's operations is not marked-to-market. This setting allows us to empirically disentangle pay for luck from pay for action, as a change in the value of real estate is only accounted for when the CEO responds to changes in property value. We show that CEO compensation is associated with the following two managerial responses to changes in real estate values: (i) real estate sales and (ii) debt issuance. Overall, we show that CEOs are rewarded for taking value enhancing actions in response to luck.
\end{abstract}

\footnotetext{
*Acknowledgments: We thank Ryan Whitby for kindly providing us with his sale-and-leaseback transaction data and Diego Garcia and Øyvind Norli for providing us with their real estate holdings data. We thank the Editor, Richard Sloan, and two anonymous referees, for their helpful suggestions. We also thank Manuel Adelino, Ulf Axelson, Mary Barth, Itzhak Ben-David, Sreedhar Bharath, Robert Bushman, Nelson Camanho, Pierre Chaigneau, Vicente Cunat, Alex Edmans, Daniel Ferreira, Miguel Ferreira, Fernando Ferreira, Marc Gabarro, Andra Ghent, Denis Gromb, Michael Hertzel, Eva Labro, Ernst Maug, Pedro Santa Clara, and Carlos Santos for helpful comments as well as conference participants at the American Finance Association meetings in Boston, the Annual Early Career Women in Finance Conference in Seattle, the Asian Bureau of Finance and Economic Research, the European Summer Symposium in Financial Markets in Gerzensee, the Lusobrasilian Finance Conference, the Workshop on Executive Compensation and Corporate Governance at the Erasmus University Rotterdam, the University of North Carolina Conference on Financial Economics and Accounting, the 4 Nations Cup Conference, and seminar participants at Arizona State University, Bocconi University, Boston University, Department of Land Economy - Cambridge University, Frankfurt School of Finance and Management, Imperial College Business School, Indiana University, Instituto de Empresa IESE-Barcelona, King's College Business School, University of Michigan, University of Minnesota, the Queen Mary University London, New York University, Northeastern University, NOVA School of Business and Economics, Portuguese Catholic University, SFI Geneva, Southern Methodist University, University of St. Gallen, University College London, Universiy of Virginia - McIntire, Warwick Business School, SC Johnson Graduate School of Management, Cornell University, and the WHU-Otto Beisheim School of Management. Bernardo Mendes and Carly Burd provided invaluable research assistance. Any errors are ours.

\$Boston University Questrom School of Business, (albuquea@bu.edu).

II Tulane University Freeman School of Business, (bbennett1@tulane.edu).

"Imperial College Business School, (c.custodio@imperial.ac.uk).

**Cornell SC Johnson College of Business, (dc998@cornell.edu).
} 


\section{Introduction}

Agency theory suggests that boards design efficient compensation schemes to provide chief executive officers (CEOs) with incentives to maximize shareholder value (Murphy, 1999; Core et al., 2002). In a traditional optimal contracting framework, shareholders should not compensate CEOs for firm performance driven by exogenous factors ("luck") (Holmström, 1979). However, several papers show evidence of "pay for luck," that is, pay that is due to observable lucky events, such as industry or market performance, and not under the CEO's control (Bertrand and Mullainathan, 1998, 2001; Bebchuk and Fried, 2003; Garvey and Milbourn, 2006; Bizjak et al., 2008). More recent agency models suggest that pay for luck can be optimal if the principal wants to incentivize the agent to forecast or respond to lucky events on the basis of her or his informational advantages (Axelson and Baliga, 2008; Göx, 2008; Noe and Rebello, 2011) or to reinforce effort incentives (Chaigneau et al., 2014). In these models, pay for luck can be interpreted as the CEO being rewarded for his or her response to a lucky event (which we refer to as "pay for action"). ${ }^{1}$

Empirical studies have not distinguished between pay for luck from pay for responses to luck. In this paper, we propose a new setting that enables us to make this distinction and study the sensitivity of CEO compensation to responses to luck. ${ }^{2}$

We use the variation in the value of firm's real estate as well as CEO's actions in response to this variation to identify pay for luck versus pay for action. In the absence of financial frictions, actions related to real estate assets (buying or selling) are value neutral for firms since all transactions are made at fair value and

therefore have zero net present value (NPV). However, when firms are financially constrained, these transactions can be NPV positive, and firms may be expected to respond to the favorable real estate market conditions to alleviate these constraints (Chaney et al., 2012; Cvijanović, 2014).

We estimate the sensitivity of CEO pay to lucky events and to responses to these events. Building on the identification strategy used in the collateral channel literature (Balakrishnan et al., 2014), we compare how changes to real estate prices impact CEO pay for firms that have different amounts of real estate assets on

their balance sheets in 1992. We measure exposure to real estate price changes prior to our estimation period to alleviate concerns that exposure is endogenously chosen by the manager. Our empirical models include CEO-firm fixed effects to deal with the endogeneity of CEO-firm matching and omitted variables at the firm, CEO, and CEO-firm levels, which implies that time-invariant characteristics of the firm or the manager, such as talent, are unlikely to drive our results. Consistent with the empirical literature, we find

\footnotetext{
${ }^{1}$ Chiu et al. (2016), for example, examine fluctuations in interest rates, exchange rates, and inflation as sources of luck in CEO compensation.

${ }^{2}$ Work on relative performance evaluation (RPE) (Albuquerque, 2009; Gong et al., 2011; Bettis et al., 2010, 2018; Lobo et al., 2018; De Angelis and Grinstein, 2011) states that the firm performance measures used to structure CEO pay contracts should exclude the component driven by luck and reflect CEO actions.
} 
that CEOs are rewarded for luck. The magnitude of the effect is economically significant: the sensitivity of CEO pay to real estate luck suggests that a one standard deviation change in the value of firm real estate is associated with an increase in CEO compensation of $\$ 57,052$, evaluated at the mean.

We proceed to estimate the sensitivity of CEO compensation to actions, focusing on three specific responses to real estate luck: sales of real estate assets, debt issuance, and sale and leaseback (SLB) transactions. We also use changes in accounting returns to comprehensively capture any action the CEO might have taken in response to changes in real estate prices. We exploit the fact that, under US accounting principles (GAAP), real estate asset values are not marked-to-market to identify CEO responses in a firm's financial statements. In response to changes in the value of firms' real estate holdings, one should expect to observe changes in firm accounting performance only if the CEO takes action. ${ }^{3}$ Using this procedure, we capture the sensitivity of pay to action by testing the sensitivity of pay to changes in accounting returns associated with changes in real estate prices.

Controlling for peer effects (Albuquerque et al., 2013; Bizjak et al., 2008), we find that the sensitivity of CEO compensation to responses to real estate price changes is positive and significant, which suggests that CEOs are rewarded for these responses. The economic magnitude of these rewards is relevant: for instance, a one standard deviation increase in real estate value induced change in ROA is associated with an increase of $\$ 32,733$ in total CEO compensation. After considering CEOs' responses to real estate value changes, our estimates of pay for luck remain overall economically and statistically significant. Note that, in cases when the optimal response of the manager to changes in real estate value is "no action," say, not selling a property, the "no action" response to luck is still embedded in the estimate of pay for luck. For this reason, our measure is conservative in capturing actions associated with real estate value changes. ${ }^{4}$ Next, we investigate whether the responses to luck are valuable for shareholders. Shareholders are expected to reward a CEO for responding to a lucky event when that action increases shareholder value (Murphy, 1999; Core et al., 2002). Even though it is arguably difficult to evaluate and directly test whether actions are optimal, because we cannot observe the counterfactual in our setting, we can still evaluate whether, on average, common responses to real estate luck add value for shareholders. To do this, we explore cross-sectional variation in firms' financing constraints and the quality of their corporate governance. The rationale is that most actions taken as a response to real estate luck, such as debt issuance

\footnotetext{
3"Real estate luck" might still be reflected in accounting returns in the following situations: extremely negative real estate shocks, when the firm can write off real estate assets, and real estate rentals. We deal with the first case by excluding extreme negative shocks from the analysis and the second by adjusting accounting returns for the effect of rental expenses. Further, since real estate assets held for sale or investment property are marked-to-market, both accounting and market performance are expected to be affected by real estate changes, despite managerial actions. These assets typically represent a very small fraction of the firms' assets, and most of firms do not hold them.

${ }^{4}$ With our identification strategy, we still cannot capture the ability of the CEO to forecast real estate price changes, and therefore compensating for this ability may still be part of the estimated pay for luck.
} 
using real estate as collateral, are more valuable for financially constrained firms. We find that rewarding CEOs for responses to real estate luck is more pronounced for financially constrained firms and for well-governed firms, suggesting that these firms incentivize their CEOs to respond to lucky real estate events or compensate them ex-post for their actions. We also run an event study on SLB transactions. We find that these transactions are associated with significant positive cumulative abnormal returns (CARs) around the announcement date, suggesting that these CEO actions are value increasing. Taken together, these results suggest that these actions create value for shareholders.

To address the concern that real estate prices are correlated with an unobserved variable not under the CEO's control but correlated with CEO compensation (e.g., aggregate demand), we use the inelasticity of land supply as an exogenous regressor for real estate prices. To mitigate measurement error related to real estate holdings outside the headquarters' location, which we use to capture real estate value changes, we use data on a firm's location-specific real estate holdings from García and Norli (2012). This test also addresses the concern that exposure to real estate markets is time-invariant in our baseline analysis by creating a time-varying measure from 1994 onward. Our results remain unchanged. In addition, we propensity-score match our treatment and control observations, based on industry and real estate exposure in 1992, and use the Bertrand and Mullainathan (2001) approach to estimate pay for luck and pay for actions. These two different approaches provide consistent empirical results. Overall, our results are robust with respect to alternative methodologies and measurement concerns. Lastly, we explore how our results vary with types of real estate news. We find that our results are mostly driven by good real estate luck and

large real estate price changes. Taken together, the totality of evidence suggests that managers are compensated for responding to real estate luck.

We build on Gopalan et al. (2010a), who show, in the context of sector performance, that managerial decisions relate to sector-performance luck. We also contribute to the debate between the managerial-power and competitive-market views of CEO compensation (Murphy, 1999; Core et al., 2002). Pay for luck is typically used as an argument in favor of the managerial-power hypothesis, as it occurs mostly in weakly governed firms (Bertrand and Mullainathan, 2001; Chhaochharia and Grinstein, 2009; Garvey and Milbourn, 2006; Bebchuk et al., 2010). This paper is one of the first to show that CEOs are rewarded for taking value enhancing actions in response to luck.

The fact that real estate assets are not marked-to-market provides some assurance that a change in accounting returns associated with a change in the value of real estate only occurs if the manager acts. We rely on the assumption that, in the context of real estate assets, accounting returns can be informative about managerial actions beyond market returns. In the absence of frictions, market returns are fully informative about managerial action, as well as any information contained in accounting returns. However, in a setting 
such as the one proposed by Axelson and Baliga (2008), where managers can have an informational advantage, this is not necessarily the case. In our setup, all managers observe the same public signal (an aggregate real estate market change) but are assumed to interpret that signal differently and to respond accordingly. Because the manager can choose whether and how to respond, contracts are expected to incentivize optimal responses. We propose that earnings-based performance measures better capture the

individual response of the manager to these lucky events, which is consistent with the notion that accounting returns and market returns are not perfect substitutes and that the former may, in some cases, offer a better signal-to-noise ratio (Sloan, 1993) to capture actions. Interestingly, we find that most evidence of pay for luck is observed through equity compensation, while evidence of pay for action is mostly observed in cash compensation, which tends to be more linked to accounting measures of performance. The rest of the paper is organized as follows. In Section 2, we provide the theoretical and institutional background to our analysis. In Section 3, we explain the data and methodology and, in Section 4, discuss the main findings. In Section 5, we address robustness tests and, in Section 6, we conclude.

\section{Theoretical and institutional background}

\subsection{Theoretical background}

Given the extensive empirical evidence on pay for luck (Bertrand and Mullainathan, 2001; Garvey and Milbourn, 2006), a number of studies offer a rationale for this phenomenon. Several studies propose pay for luck as a mechanism to incentivize effort, for instance, effort to generate informative signals about the market. Axelson and Baliga (2008) argue that, when managers receive private signals about industry or

market performance, it is optimal to pay them for exogenous performance, so that the managers would act on the private signal in a way to maximize firm value. Gopalan et al. (2010a) make a similar argument that pay for industry performance is optimal when the principal wants to incentivize an optimal exposure to sector movements and this exposure is under the CEO control. Empirically, they find that pay for industry performance is mostly found in firms in which the CEO has greater strategic flexibility with respect to sector exposure.

Our paper supports the theory of Gopalan et al. (2010a) by showing that pay for luck might be optimal when the board wants to provide incentives for an optimal response to a lucky event that is presumably under the CEO's control, as evidenced, for example, by SLB transactions or sales of real estate. Evidence of pay for luck can also be rationalized by the CEO being compensated for responding optimally to a lucky event, assuming the response is observable to the board. We explicitly identify these responses and test 
whether managers are paid for responding to changes in the real estate market conditions.

Similar to Axelson and Baliga (2008), in our setup, all managers observe a public signal (aggregate real estate price changes); however, managers have different private interpretations of the same public signal. Depending on the managers' private interpretation, they then choose whether to respond to a (positive) exogenous (real estate) event in such a way as to improve the firm's performance. This is consistent with the argument in Axelson and Baliga (2008): contracts should tie compensation not only to measures that relate to pure effort but also to those about which the manager is likely to have better information than the market. This is precisely the case in our setting: because the manager can choose whether and how to respond to the exogenous events, contracts should incentivize optimal responses. ${ }^{5}$

\subsection{Institutional background}

\subsubsection{Accounting treatment of long-lived assets under US GAAP}

Real estate assets are typically recognized on the balance sheet as property, plant, and equipment, at acquisition cost, and depreciated on a systematic basis over time. Changes to the value of firm real estate are reflected in its market and accounting performance in different ways. When the value of a firm's real estate changes as a result of an increase in real estate prices, this change in firm value should be reflected in its market capitalization (and therefore in its stock market performance) immediately, assuming markets are efficient. However, according to US GAAP, the exact same change should not be reflected in the firm's accounting performance. Based on the historical-cost principle, under GAAP, long-lived assets (such as real estate) are recorded on the balance sheet at historical cost, even if their values have significantly increased over time. Historical cost is a measure of value in which the price of an asset on the balance sheet is based on its nominal or original cost when acquired by the company. Given that the value of a firm's real estate is not marked-to-market, any changes to the firm's accounting performance due to a real estate value change must come from a firm (or its $\mathrm{CEO}$ ) reacting to that change in some way: for instance, selling the real estate and realizing a capital gain (or loss). The US GAAP historical-cost principle thus provides a setting that allows us to estimate the sensitivity of CEO pay to responses to luck, because accounting performance is not affected by real estate value changes, unless there is an action taken by the CEO. ${ }^{6}$

\footnotetext{
${ }^{5}$ An alternative explanation draws on the arguments of Axelson and Bond (2015) and DeMarzo et al. (2012), who predict that rewarding the manager for luck is optimal in good times, because boards want to incentivize managers to seek positive NPV projects when the times are good. To do so, they may want to tie managerial compensation to measures that are beyond managers' control. In this paper, we show that CEOs are indeed compensated for taking value increasing actions during good (real estate) times.

${ }^{6} \mathrm{~A}$ real estate asset can also be accounted for as property held for sale, when the firm holds the asset with the purpose of selling it. In this case, the asset is measured at the lower of its carrying amount or fair value, less costs to sell, and the asset is not depreciated as it is not being used in the firm's operations. For this kind of asset, because it is marked-to-market, both accounting and market performance are affected by real estate value changes, despite managerial actions. Non-current real estate assets held for sale typically represent a very small fraction of firms' assets, and most of firms do not hold them. (In our sample, only four firm-year observations had such assets.) Significant decreases in real estate prices can lead firms to perform impairments of their property. An asset is impaired when
} 


\subsubsection{Reactions to events that are not under CEO control}

Following an increase in the value of the firm's real estate holdings, the CEO can respond in several ways. As an example, the CEO can sell the real estate assets and relocate. Alternatively, the CEO can sell the real estate assets and lease them back (to perform an SLB), or change the financing policy of the firm by issuing more debt while taking advantage of the increase in collateral value. In this section, we discuss the institutional details behind SLB transactions, as the process of issuing debt following an increase in real estate values is well understood in the collateral channel literature (Chaney et al., 2012; Cvijanović, 2014). As argued by Whitby (2013), the choice to enter into an SLB transaction is an example of an instance where the manager decides to change the way the firm finances its assets. In an SLB transaction, an asset is sold to a third party at a gain, usually a real estate investment trust (REIT), and then simultaneously leased back

with little or no impact to the daily operations of the firm and the use of that asset. The accounting treatment for an SLB transaction under ASC 840 states that the amount of the gain recorded by firms at the time of the sale depends on the significance of the lease in comparison to the fair value of the property. ${ }^{7}$ Most corporate SLBs involve real estate (Whitby, 2013). Ben-David (2005) reports that the most common assets involved in SLB transactions in his sample were the company's headquarters, followed by retail locations. As he shows, the top two declared motives for entering into an SLB transaction are to use the cash proceeds to reduce debt and for expansion.

As anecdotal evidence, Sotheby's announced in a press release in 2002 that it had engaged in an SLB deal involving its New York headquarters. The CEO, Bill Ruprecht, was clear about the motivation: "This is an outstanding opportunity for Sotheby's. ... The attractive price of $\$ 175$ million reflects the high asset quality, desirable location and Sotheby's bright future prospects. Sotheby's ... decided to enter into an SLB transaction as a means of financing to provide long-term liquidity for our business. It will also allow Sotheby's to pay down $\$ 100$ million in short-term debt. ..."

Studies show that corporate real estate SLB transactions add value to shareholders (see, for instance, Slovin et al. (1990), and Rutherford (1990) and, for more recent evidence, Ben-David (2005) and Whitby (2013)). In addition, shareholder activists often push firms to "monetize" the increase in value of their real estate by engaging in SLB transactions, which allow firms to generate cash for stock buybacks, dividends, investments in valuable projects, or debt repayment. Additional evidence that SLB transactions can be

its market or fair value is less than its value recorded on the firm's balance sheet. In this case, the value of the asset is written down to its current market price and could result in ROA containing losses attributable to substantial declines in fair value. We re-estimate our main analysis while excluding from the analysis the top one percent largest declines in real estate prices and obtain similar results.

${ }^{7}$ Under ASC 840 if the future rental payments, as a percentage of the fair value of the property, are less than $10 \%$, the full gain is recognized. If the percentage is between $10 \%$ and $90 \%$, a partial gain is recognized. And if the percentage is above $90 \%$, then recognition of the gain occurs through amortization over the lease term. For more details, see https://asc.fasb.org. Also note that during the period of study, 1992-2016, operating leases were off-balance sheet. A new FASB rule, effective Dec. 15, 2018, requires that all leases - unless they are shorter than 12 months - must be recognized on the balance sheet. 
value increasing for firms is the fact that compensation committees explicitly mention their completion when evaluating CEOs' performance.

To assess whether CEOs are rewarded for engaging in SLB transactions, we parsed all DEF 14A filings (proxy statements) obtained from the SEC website for our sample firms. We devised an algorithm to classify a firm-year observation as mentioning an SLB transaction if, in the company's proxy statement, we found the word "leaseback." This resulted in a sample of 1,167 firm-year observations. Given that firms are expected to engage in SLB transactions following increases in RE value, this means that about $38 \%$ of the firm-year observations with an yearly change in real estate prices in the top quartile (good real estate luck) in our sample mention a SLB transaction in their proxy statement. We then read the proxy statements to confirm that CEO compensation was associated with an SLB transaction. We found that, for 113 firm-year observations, SLB transactions were mentioned when discussing CEO performance and, for 13 firm-year observations, the fact that the CEO was being compensated for such a transaction was mentioned. (See

Appendix B for examples.) Similar to the findings of Ben-David (2005), the most often cited reason mentioned by firms in our sample for doing an SLB transaction was the use of cash proceeds to repay debt. $^{8}$

\section{Data and methodology}

Many studies analyze whether CEOs are rewarded for lucky events. The standard approach by Bertrand and Mullainathan (2001) consists of estimating the sensitivity of CEO compensation to changes in firm performance driven by luck, using exogenous determinants of firm performance, such as oil prices or exchange rates. However, when estimating the sensitivity of compensation to luck in this framework, one cannot disentangle the sensitivity of pay to luck from the sensitivity of pay to responses to luck (actions) because the luck and responses are empirically indistinguishable.

The accounting treatment of real estate assets described in Section 2.2.1 allows us to distinguish luck from responses to it: given that any changes to the value of a firm's real estate should only be reflected in the

firm's financial statements if there was an action in response to the change. Thus we can identify the sensitivity of CEO pay to luck (measured by the change in the market value of its real estate assets) as well as the sensitivity of pay to reactions to luck (measured by the changes in accounting outcomes).

\footnotetext{
${ }^{8}$ To assess whether CEOs are rewarded for gains associated with real estate sales, we also parsed out all DEF 14A filings for our sample firms using the following words "real estate sale," "gains on sale of real estate," "gains on sale of property," "gains on sale of pp\&e," "gains on sale of ppe," and "gains on sale of assets." We found only 18 firm-year observations. We found examples where the gain on sale of property is explicitly mentioned as being included when deciding on the compensation of the CEO as it was "pursuant to the long-term strategic plan for the Company" (e.g. Churchill Downs Incorporated (CDI) for fiscal year 2016). However, in other cases, gains on sale of assets were excluded (e.g., Service Corporation International for fiscal year 2014). The fact that we find cases where gains on sales of assets are both excluded and included is consistent with prior work (Black et al., 2020; Curtis et al., 2021; Potepa, 2020).
} 


\subsection{Data}

Our initial sample consists of a CEO-firm year panel of Standard and Poor's (S\&P) 1,500 firms drawn from

the Execucomp database, from 1992-2016. We then match this sample to the CRSP and Compustat databases to obtain stock returns and accounting data and to the Federal Housing Finance Association's (FHFA) database of CBSA-level house price data. We exclude firms in the finance, insurance, real estate, construction, and mining industries as well as those involved in a major takeover operation, following the

literature (Chaney et al., 2012). By excluding these firms, we also ensure real estate assets are not marked-to-market, which is key to our identification. Our SLB data corresponds to the data in Whitby

A key construct in our research design is the effect of changes in real estate prices on the value of a firm's real estate holdings. To construct this variable, we first measure the market value of a firm's real estate assets. There are three major categories of property, plant, and equipment included in the definition of real estate assets: buildings, land and improvement, and construction in progress. To arrive at the measure of a firm's real estate assets, we follow two steps. In Step 1, we measure a firm's owned real estate assets in 1992 as the total net book value of property, plant, and equipment (Compustat variable PPENT) less the net book value of leased assets (Compustat PPENLS), less the net book value of equipment and machinery

(Compustat PPENME), thus yielding the total net book value of a firm's land and improvements, buildings, and construction in progress. Under US GAAP, these items represent the respective capitalized values, less accumulated depreciation. Net book value of property, plant and equipment (Compustat variable PPENT) excludes land and property held for sale. We replace missing observations with zeros.

This variable is scaled by total assets to obtain the portion of the firm's assets related to its real estate holdings, as measured in 1992. In subsection 5.1, we explicitly follow Chaney et al. (2012) and Balakrishnan et al. (2014) to construct a more precise measure of the firm's real estate holdings that accounts for the acquisition year and discuss the trade-offs we consider.

In Step 2 and following Balakrishnan et al. (2014), we use real estate prices indices to estimate the market value of real estate assets in 1992 and then track the change in the market value of these assets over the sample period as a function of changes in real estate prices. We obtain the house price data from the Federal Housing Finance Association (FHFA). These data are calculated at the level of a core-based statistical area (CBSA). ${ }^{9}$ The data contains a quarterly CBSA-level house-price index for 369 CBSAs from 1986 to 2016. The choice to use residential prices, instead of commercial real estate prices, is driven by the

${ }^{9} \mathrm{~A}$ CBSA is a geographic area defined by the Office of Management and Budget (OMB) based around an urban center of at least 10,000 people and adjacent areas. CBSAs largely overlap with Metropolitan Statistical Areas (MSA) also defined by the $\mathrm{OMB}$, and we use the two acronyms interchangeably throughout the paper. For further details, see: https://www2.census.gov/geo/pdfs/reference/GARM/Ch13GARM.pdf. 
lack of availability of reliable commercial real estate data at MSA level for the period in question. Namely, most publicly available sources report state prices indexes for offices, excluding other types of commercial real estate.

We estimate the market value of real estate assets in 1992 as the book value of real estate assets in 1992 from Step 1 multiplied by the value of the MSA real estate price index of the firm's headquarters. ${ }^{10}$ We then estimate the market value of real estate assets in each subsequent year as the market value of a firm's real estate assets in 1992 multiplied by the cumulative real estate price increase from 1992 to a given year.

The CEO-firm year data is merged to the house price data by linking each firm's headquarters zip code

(from Compustat) with its particular CBSA using data from US Department of Housing and Urban Development (HUD) database. HUD provides HUD-USPS crosswalk files, which allocate zip codes to CBSAs.

We use ExecuComp to obtain or calculate the following variables used in our analysis: cash compensation, equity compensation, total compensation, tenure, and age. Our primary dependent variable is total pay, which consists of salary, bonus, non-equity incentive payout, value of restricted stock granted, value of options granted, and other compensation (ExecuComp item TDC1). In our regressions, we control for firm size using the logarithm of firm total assets, firm growth opportunities using Tobin's $Q$, accounting profitability using ROA and stock return, and stock price volatility. Following Bertrand and Mullainathan (2001), we also control for CEO age and CEO age squared. Finally, we obtain blockholder data from Thomson Reuters.

The final dataset includes 14,838 CEO-firm year observations from 1992-2016. All variables are winsorized at the first and 99th percentile values. Appendix A provides variable definitions and data sources.

\subsection{Methodology}

\subsubsection{Pay for luck}

In the spirit of the literature (Aggarwal and Samwick, 1999; Bertrand and Mullainathan, 2001; Garvey and Milbourn, 2006; Chhaochharia and Grinstein, 2009), we start by testing whether CEOs are compensated for lucky events, as proxied by changes in real estate values. We estimate the following baseline specification.

$$
\log \left(\text { TotalComp }_{c, i, t}\right)=\alpha+\beta_{1} \text { RE_Value }_{i, t}+\beta_{2} H P I_{m, t-1}+\sum_{x} \beta_{X} X_{i, t}+\gamma_{i, c}+\delta_{j, t}+\varepsilon_{c, i, t}
$$

where TotalComp $p_{c, i, t}$ is total CEO compensation of CEO $c$ in firm $i$ at time $t . R E_{-} V a l u e_{i, t}$ is the market value

\footnotetext{
${ }^{10}$ The assumption here is that most of a firm's real estate holdings are located in the same MSA as its headquarters and that this is time-invariant, as measured in 1992. We relax these two assumptions in Section 5.2.
} 
of real estate in 1992 multiplied by the MSA-level real estate price index from 1992 to year $t$ :

$$
R_{-} \text {Value }_{i, t}=\left(\text { RE_Value }_{i, 1992} \times H P I_{m, t}\right) \text {. }
$$

Following Chaney et al. (2012) and Balakrishnan et al. (2014), we measure the value of a firm's real estate in 1992, RE_Value ${ }_{i, 1992}$, prior to our estimation sample, thus excluding any acquisitions or dispositions in subsequent years. An advantage of this approach is that it mitigates potential endogeneity concerns in that the variation in market value of a firm's real estate is driven solely by changes in real estate prices (which are outside the manager's control) and not by firm's investments (which are under the manager's control). A disadvantage of this approach is that it creates a potential measurement bias since the value of a firm's real estate in any given year will not be precisely estimated. We address this issue and use a time-varying exposure measure in Section 5.2. ${ }^{11}$

The variable $R E_{-} V_{a l u e}, t$ has two sources of variation, given that firms had different exposure to real estate market fluctuations in 1992, as indicated by different amounts of real estate assets in that year. The first source is cross-sectional variation stemming from the initial value of real estate assets in 1992 . The second source is driven by time-series variation in the market value of these assets due to time-variation in real estate prices. Our identification uses this source of variation to capture events that are outside of the CEO's control. Since real estate prices are not under managerial control, $R E_{-} V_{a l u} e_{i, t}$ in Equation 1 thus represents the firm-specific luck measure. ${ }^{12}$

To control for changes in real estate prices in an MSA where the firm is located, we include $H P I_{m, t-1}$ in

Equation 1. This variable also serves as a control for local, MSA-level economic conditions, which might be driving our variable of interest. $X_{i, t}$ are firm and CEO-specific controls, such as ROA, total assets, market-to-book of assets ratio, stock return volatility, stock return, CEO age, and CEO age squared.

Following prior studies (Faulkender and Yang, 2010), we also control for lagged performance metrics:

ROA and stock returns.

\footnotetext{
${ }^{11}$ Note that Equation 1 resembles the Aggarwal and Samwick (1999) specification, except that their measure of luck is industry performance whereas ours is changes in real estate value. Similarly, we measure firm performance using both stock and accounting returns, whereas they measure firm performance using the dollar return to shareholders. In untabulated results, we replicate our tests via the Aggarwal and Samwick (1999) specification by using the dollar return to shareholders returns and further controlling for the performance of firms in the same industry, measured by the dollar return of the (weighted average) industry performance to shareholders, and find qualitatively similar results.

${ }^{12} \mathrm{To}$ address the concern that firms can drive real estate prices, that is, that CEOs actions can affect local RE prices, we perform two tests. First, we create an exogenous source of variation in MSA-level real estate prices using a measure of land supply inelasticity interacted with aggregate changes in real estate prices at the national level, as captured by the U.S. Case-Schiller House Price Index (see Section 5.4), and obtain similar results. Second, in the spirit of Chaney et al. (2012), we address potential reverse causality concerns whereby a large firm's actions may increase local real estate prices. We re-estimate our main specifications using a subsample of small firms located in large MSAs. We consider only firms in the lower three quartiles of size and in the largest 20 MSAs. Untabulated results of this analysis remain similar to our baseline estimates.
} 
To address a potential concern that there is matching between a firm's real estate exposure and CEO type or between its location and CEO type that might be driving our results, we include firm-CEO fixed effects, $\gamma_{i, c}$, as noted above. In this way, our main source of variation comes from tracking the same CEO-firm pair over time. In addition, the inclusion of firm-CEO fixed effects controls for time-invariant unobservable characteristics of the CEO, such as talent or risk preferences, that have been shown to explain much of the variation in CEO compensation (Graham et al., 2012).

As noted by Albuquerque et al. (2013), Bizjak et al. (2008), and Cadman and Carter (2013), boards tend to structure CEO compensation contracts based on peer CEO (firm) compensation. The inclusion of industry-year fixed effects, $\delta_{j, t}$, serves as a control for peer effects: thus $\beta_{1}$ captures the general sensitivity of pay to (real estate) luck, relative to other CEO-firm pairs that operate in the same industry. ${ }^{13}$ By including industry-year fixed effects $\delta_{j, t}$, we also implicitly control for macroeonomic conditions that vary across industry and time. Note that, since our model includes firm-CEO fixed effects, this gives the coefficients a changes interpretation. The coefficient of interest is $\beta_{1}$, which captures the sensitivity of CEO pay to (real estate) luck for a given firm-CEO pair over time, controlling for time-varying industry-specific characteristics that might be driving our results. ${ }^{14}$

Without the appropriate cross-sectional and inter-temporal fixed effects (e.g., firm and year effects), the correlation between CEO pay and real estate values could simply be driven by industry or time series variation. For example, tests without these controls would compare relatively lower pay for executives in the utilities industry away from the coasts, where real estate prices are low, with relatively higher pay for executives in the technology industry in Northern California, where real estate prices are high. Further, CEO compensation and real estate prices increase through time. This would deliver a positive correlation between the two, but we cannot interpret that correlation as pay for luck. At the same time, finding a negative correlation between compensation and market value of real estate would not be incompatible with CEOs being paid more when real estate prices increase (pay for luck) or CEOs being paid more when they respond to luck, as this correlation could be driven by variation across firms and not within the firm.

\footnotetext{
${ }^{13}$ In untabulated robustness tests, we alternatively include industry-size-year fixed effects, which assumes that peers are firms in the same industry, size quartile (measured by the firm's market value of equity), and obtain similar results. In addition, we also obtain similar (untabulated) results when we include the average stock return of peer firms in the same industry-size quartile to capture the impact that relative performance evaluation has on CEO pay, while including industry-year fixed effects.

${ }^{14}$ In the presence of high dimensional fixed effects, the within-firm estimation may absorb relevant (true) variation, exacerbating the weight of measurement error, which works toward finding a significant correlation (rejecting the null hypothesis). Jennings et al. (2020) argue that measurement error does not always bias the estimates against finding statistically significant effects (not rejecting the null). We deal with measurement error in Section 5.1 and 5.2.
} 


\subsubsection{Pay for action}

As described in Section 2.2.1, given that any changes to the value of a firm's real estate are reflected in its financial statements only if there is an action in response to the change, we can disentangle the sensitivity of CEO pay to luck (measured by the change in market value of its real estate assets) from the sensitivity of pay to reactions to luck. Given that the value of a firm's real estate assets is not marked-to-market in financial statements, any changes to the firm's accounting performance that are associated with a change in real estate value must come from a firm (or its CEO) responding to that change in some way: for instance, the $\mathrm{CEO}$ decides to buy or sell real estate and realizes a gain (or a loss) for the firm. This motivates the following specification:

$$
\begin{gathered}
\log \left(\text { TotalComp }_{c, i, t}\right)=\alpha+\beta_{1} \text { RE_Value }_{i, t}+\beta_{2} \text { RE_Value }_{i, t} \text { XAction }_{i, t}+\beta_{3} \text { Action }_{i, t}+\beta_{4} \text { HPI }_{m, t-1}+ \\
\sum_{x} \beta_{X} X_{i, t}+\gamma_{i, c}+\delta_{j, t}+\varepsilon_{c, i, t}
\end{gathered}
$$

where Action $_{i, t}$ is one of our four proxies for responses to luck: return on assets (ROA), real estate sales, debt issuance, and SLB transactions. The coefficient of interest is $\beta_{2}$, which captures the sensitivity of CEO pay to reactions to real estate luck, as proxied by the interaction of one of the action measures $\left(\right.$ Action $\left._{i, t}\right)$ with firm-specific real estate luck $\left(R E_{-} V a l u e_{i, t}\right)$. As in Equation 1, we include a vector of time-varying firmand CEO-specific controls. The inclusion of time-varying industry specific characteristics $\delta_{j, t}$ ensures that

we are comparing the CEO pay sensitivity to responses to luck, relative to other CEO-firm pairs that operate in the same industry and year. As above, we also include firm-CEO fixed effects, $\gamma_{i, c}$.

Following Chaney et al. (2012) and Balakrishnan et al. (2014), we cluster standard errors at the MSA and year level. Our clustering procedure is appropriate because executive pay levels and real estate values are likely (serially) correlated within an MSA (Bertrand et al., 2004). Clustering the standard errors addresses the concern that the error term is correlated within groups. Because we use two-way clustering (MSA and year), our inferences are robust to the possibility that there is correlation in the error term within MSAs over time and within each year across MSAs.

Note that real estate price changes could proxy for changes in growth opportunities. If a company's real estate ownership decision is correlated with its expected growth opportunities, the estimated sensitivity of CEO pay to real estate prices will be biased upward. To address this issue, we conduct a series of tests.

First, we exclude from our estimation sample firms that operate in real estate and construction industries.

Second, we include controls for future growth opportunities in our baseline estimation: Tobin's q, MSA-level real estate prices, and year fixed effects. Further, in Section 5.4, we explicitly control for a firm's 
decision to own real estate.

\subsubsection{Measures of responses to real estate luck}

We use four alternative proxies to capture managerial responses (or actions) to real estate luck $\left(\operatorname{Action}_{i, t}\right)$. We measure our first proxy, real estate asset sales (RE_Sales), based on $R E \_C h a n g e$, which is calculated using the difference in the balance sheet value of a firm's real estate assets between year $t$ and year $t-1$ plus depreciation, scaled by lagged total assets:

$$
R E_{-} \text {Change }=\left(R E_{-} \text {Assets }_{t}-R E_{-} \text {Assets }_{t-1}+\text { DepreciationExpense }_{t}\right) / \text { Total Assets }_{t-1},
$$

where $R E \_$Assets is the sum of the balance sheet values for buildings, land and improvement, and construction in progress net of accumulated depreciation $($ RE_Assets $=($ PPENT - PPENLS - PPENME $))$. We add back depreciation to ensure that decreases in net real estate assets do not capture instances where depreciation expense exceeds capital expenditures. Variable $R E \_S a l e s$ then takes $R E \_C h a n g e$ and assumes either a value of zero (when RE_Change $>0$ ) or the assumed value of the real estate sale (absolute value of $R E \_$Change if negative). Because this is a conservative measure of real estate sales, as depreciation expense also includes depreciation for nonreal-estate assets, we also rely on the value of Compustat variable SPPE

"Sale of Property" scaled by lagged total assets to measure sales when RE_Sales $=0 .{ }^{15}$

We calculate our second proxy, long term debt issues (LT_Debt_Issues), as the change in long term debt (Compustat item DLTIS), scaled by lagged total assets. Cvijanović (2014) shows that there is a spillover effect of real estate markets on firm investment through the value of the firm's collateral, which influences its debt capacity. Issuing new debt is therefore a possible response of the $\mathrm{CEO}$ to a positive real estate shock. In our tests, we focus on long term net debt issuance, since changes in firm collateral values are more likely to affect long term borrowing secured by real estate assets.

Our third proxy is a sale and leaseback $(S L B)$ transaction, which is another possible response to real estate shocks. Using data from Whitby (2013), which covers the period of 1992 to 2011, we identify firms that engaged in an SLB transaction in a particular year. We construct an indicator variable $S L B$ that takes the

value of one if a firm was involved in an SLB transaction in a particular year and zero otherwise.

Finally, we perform an additional test that examines changes in accounting performance of the firm, our fourth proxy, as measured by its $R O A$, in a catchall approach that can include gains from sales of real estate or a decrease in interest expense. ${ }^{16} R O A$ is defined as net income divided by total assets. We use net income to ensure we capture any type of action that the manager might have taken as response to real estate value

\footnotetext{
${ }^{15}$ We thank the reviewer for suggesting that we add depreciation expense and rely on SPPE to also identify real estate sales.

${ }^{16}$ If instead the CEO exploits the increase in collateral to issue more debt, then ROA could decrease, due to the higher interest expense. The conflicting predictions regarding the impact of the real estate value change on ROA impedes detection of any association between CEO pay and changes in ROA that relate to the real estate value change.
} 
changes. Since changes in value of a firm's real estate assets is not marked-to-market, we should only observe changes in its ROA that are associated with real estate changes if a CEO responds to the real estate luck. All continuous variables are winsorized at the first and 99th percentile, and their detailed descriptions are provided in Appendix A.

\section{Results}

\subsection{Descriptive statistics}

Table 1 reports summary statistics for CEO compensation, firm characteristics, and real estate market variables. The average CEO in this sample has a total compensation of $\$ 5.3$ million. The average cash component is $\$ 2.2$ million, while the average equity component is $\$ 3.1$ million. These numbers comport with the literature on CEO compensation using similar data (Chhaochharia and Grinstein, 2009; Fahlenbrach, 2008; Gopalan et al., 2010b). The average real estate holdings as a percentage of assets is $30.4 \%$.

\subsection{Pay for luck}

Table 2 Panel A presents our initial test of the effect of real estate value changes on CEO pay. The independent variable of interest is the market value of real estate assets $R E \_V a l u e$, as defined in Equation 2. The baseline specification includes CEO-firm fixed effects, which means that identification is achieved through within firm-CEO variation. Thus the variation in the variable of interest results from changes in the market value of the real estate assets over time for the same firm-CEO pair. The estimated coefficient is 0.065 in Column 1, and 0.028 in Column 2. This suggests that, for a one standard deviation change in the value of a firm's real estate holdings, CEO compensation increases by between approximately $\$ 132,443$ and $\$ 57,052$, evaluated at the mean. ${ }^{17}$ In Column 2, we estimate pay for luck in a specification that includes industry-year fixed effects. ${ }^{18}$ The coefficients reported are obtained using heteroscedasticity-adjusted standard errors, which are double clustered at the MSA and year levels (Balakrishnan et al., 2014). ${ }^{19}$

\footnotetext{
${ }^{17}$ Using the estimated coefficient in Column 1: $(0.065)(0.381) \times \$ 5.35$ million $=\$ 132,443$. Using the estimated coefficient in Column 2 yields $\$ 57,052$.

${ }^{18}$ In untabulated tests that exclude cross-sectional fixed effects, we find a negative association between CEO pay and $R E \_V a l u e$. As mentioned above, this negative association could capture variation across firms and not within firms.

${ }^{19}$ Despite including the same control variables across specifications, the number of observations is not the same because of the different fixed effects structure. We use reghdfe command in STATA, which drops singleton observations.
} 


\subsection{Pay for action or responses to luck}

In Table 3, we test whether CEO compensation is correlated with specific responses to changes in real estate asset value (luck). In Column 1, the coefficient of interest is the interaction between ROA and real estate value: $R E \_$Value $\times$ROA. The estimated coefficient is 0.105 and it is significant at the $5 \%$ level, which means that, for a one standard deviation increase in $R E \_$Value $\mathrm{x} O A, \mathrm{CEO}$ compensation increases by $\$ 32,733$, when evaluated at the mean. This result suggests that CEOs are rewarded for their responses to changes in real estate prices, as proxied by $R O A$. Our interpretation is that this variable can capture, in a more comprehensive manner, responses to changes in real estate prices. ${ }^{20}$

In Column 2, the coefficient of interest is the interaction between real estate asset sales and the value of real estate $R E \_V a l u e \times R E \_S a l e s$. This term captures real estate asset sales associated with changes in the market value of the firm's real estate assets. Since real estate assets are not marked-to-market but held at book values, negative changes in a firm's real estate assets only occur if there is a managerial response to real estate prices (sale of real estate assets). Therefore we interpret the coefficient of this variable as the sensitivity of pay to responses to real estate luck. The estimated coefficient is 0.085 , but it is not precisely estimated (the associated $t$-stat is 1.57). In Column 3, we estimate the same specification without the non-interacted $R E \_S a l e s$ term, since the Pearson (Spearman rank) correlation between this variable and the interacted term is $0.78(0.99)$, as reported in Panel B, Table 1. The estimated coefficient is now 0.056 and statistically significant at $1 \%$ significance level. The estimated monetary effect for a one standard deviation increase in $R E \_$Value $\mathrm{x} R E \_S a l e s$ when evaluated at the mean is between $\$ 2,996$ and $\$ 4,548$.

Due to high correlation between action variables (RE_Sales, LT_Debt_Issues, and SLB) and their interaction with $R E_{-}$Value, we do not include the non-interacted terms in the rest of the analysis. As shown in Table 1, the Pearson (Spearman) correlation between these action variables and their interaction with $R E \_$Value ranges between 0.74 and 0.78 (0.97 and 1.00). Untabulated results show that the correlation

between the action variables demeaned by CEO-firm and industry-year and their interaction with the demeaned $R E_{-}$Value are very similar to raw Pearson (Spearman) correlations. The exception is LT_Debt_Issues where the Pearson (Spearman) correlation drops from $0.74(0.97)$ to 0.55 (0.57) for the demeaned variables, likely due to the fact that leverage tends to be industry and year specific. In addition, likelihood ratio tests (whether a model without the non-interacted term provides as good a fit to the data as the model that includes it) suggest that the inclusion of the non-interacted term does not provide a statistically significant improvement to the model.

Columns 4 and 5 show similar results for LT_Debt_Issues: the estimated coefficients on the interaction

\footnotetext{
${ }^{20}$ We make use of $R O A$ as our main action variable in the setting proposed by Bertrand and Mullainathan (2001) and find consistent results in Table C1.
} 
term RE_Value x LT_Debt_Issues range between 0.017 in Column 5 and 0.037 in Column 4. The economic effect of a one standard deviation increase in the interacted term on total compensation is estimated to be between $\$ 3,931$ and $\$ 8,595$. Column 5 shows the results without the non-interacted debt term

$$
\text { LT_Debt_Issues. }
$$

Lastly, Columns 6 to 7 show the results for SLB transactions: the estimated coefficient on the interaction term, $R E \_$Value $\mathrm{x} S L B$, is positive but not statistically significant. We note that firms tend to "monetize" the increase in value of their real estate by engaging in SLB transactions, which means that these transactions can result from past increases in real estate values. The estimated coefficient on SLB is positive (0.028) and significant at 5\% level, which means that CEO compensation increases by $\$ 149,744$, when evaluated at the mean, following an $S L B$ transaction, regardless of real estate luck in the most recent period. Since we run all regressions with industry-year fixed effects, we filter out the common yearly industry component of these action variables, which means that our results only capture responses to real estate value changes that are not common to the whole industry. ${ }^{21}$

As mentioned before, standard errors are calculated using two-way cluster at MSA and year. Conley et al. (2018) specifically raise the issue regarding a small number of clusters in Balakrishnan et al. (2014), who have a similar setting to ours. In our case, approximately $90 \%$ of our observations correspond to firms that have between 10 and 24 years of data, which mitigates this concern. Nevertheless, in Appendix D, we restrict our sample to firms that have more than 10 years of data and show consistent results.

The results of this section further support the notion that CEOs are rewarded for their responses to real estate luck, across different measures of action: RE_Sales, the "catchall" variable ROA, and LT_Debt_Issues transactions.

\subsection{Cash and equity pay}

In Table 4, we repeat our analysis differentiating between cash and equity compensation. We expect most of pay for luck to occur through equity compensation, as the stock price of the company, assuming some degree of market efficiency, should reflect the market value of the real estate assets of the firm. We measure equity grants using the fair value at grant date, which can occur at different times throughout the fiscal

year for different firms. The equity grants thus relate mechanically to stock returns and thus can incorporate higher $R E_{-}$Value. On the other hand, we do not expect CEOs to be rewarded for luck using cash compensation, as that would be harder to justify to shareholders.

Columns 1-7 show the regression results for cash compensation. We do not find evidence of pay for luck

\footnotetext{
${ }^{21}$ In untabulated tests that exclude cross-sectional fixed effects, we find that the interaction terms of $R E \_$Value with various measures of action (i.e., ROA, RE_Sales, and LT_Debt_Issues) are positive and significant. The interaction term of RE_Value and SLB is no longer significant at conventional levels.
} 
through cash compensation, as the coefficient on $R E_{-}$Value is negative and insignificant across the different specifications. But we do find that CEOs are rewarded in cash compensation for taking actions using three of our action measures: sales of real estate $R E \_S a l e s, S L B s$, and through the catchall measure, $R O A$. Columns 8-14 show regressions using equity compensation. As expected, we find evidence of pay for luck through equity compensation despite accounting for responses to luck in the regressions. We also find that equity pay is positively associated with the action variable $L T_{-} D e b t_{-} I s s u e s$, which is consistent with debt issues being in general positively perceived by investors.

Overall, the results presented in this section suggest that CEOs get rewarded using equity, not cash, for real estate luck. In contrast, when we test pay for action, we find that cash compensation is associated with most responses to luck, whereas equity compensation is not, suggesting that compensation responses to changes in real estate prices happens mostly through cash bonuses. ${ }^{22}$ Since the evidence using total compensation suggests that CEO's are rewarded for SLB transactions, regardless of luck, we exclude this variable from the rest of the analysis.

\subsection{Is pay for luck optimal?}

We now discuss the optimality of incentivizing and paying CEOs to respond to real estate luck. It only makes sense for the board to incentivize the CEO to respond to luck if such responses are optimal for shareholders. Even though it is arguably difficult to evaluate and directly test whether these actions are optimal, since we cannot observe a counterfactual, we can still evaluate whether, on average, responses to real estate luck add value to shareholders. To do this, in this section, we explore cross-sectional variation in the level of financial constraints and in corporate governance. In Appendix E, we run an event study on SLB transactions. We find that SLB transactions in general generate significant cumulative abnormal returns (CAR) between $1.3 \%$ and $1.4 \%$.

\subsubsection{Pay for responses to luck and financing constraints}

In this section, we study heterogeneous effects of responses to changes in real estate prices for firms with different levels of financial constraints. We focus our analysis on the action variable LT_Debt_Issues, which is arguably an optimal response to increases in real estate values when firms are financially constrained. In addition, issuing debt does not have a direct impact on a firm's operational activities. In contrast, a firm's decision to relocate its headquarters (captured by the action variables $R E \_S a l e s$ and $R O A$ ) results from

\footnotetext{
${ }^{22}$ In untabulated analysis, we test whether CEOs are rewarded for pay for action using discretionary bonuses (the variable "Bonus" from Execucomp captures discretionary bonus after 2006), which are available for about half of our sample (6,896 firm-year observations). We find a positive association between discretionary bonus and the action variables ROA, RE_Sales and LT_Debt_Issues, although the results are not precisely estimated for $R E \_S a l e s$.
} 
strategic considerations, such as labor market conditions, corporate taxes, the proximity to business services (e.g., airport), or a merger. For this reason, we focus this analysis on the action variable

$$
\text { LT_Debt_Issues. }
$$

Table 5 shows the results for firms with different levels of financial constraints. Following the literature (Almeida et al. (2011); Campello and Hackbarth (2012); Hadlock and Pierce (2010)), we use the firms' previous year's dividend payout and the Whited and $\mathrm{Wu}(2006)$ index $(\mathrm{W}-\mathrm{W})$, as proxies for the level of financial constraints. In the spirit of Almeida et al. (2011), for each year in our sample, we classify firms as financially constrained (unconstrained) if their dividend payout is below (above) the median within the year. We also employ the Whited-Wu index: each firm with Whited-Wu index value above (below) the median within the year is assumed to be constrained (unconstrained). We find that evidence of pay for responses to luck in the form of LT_Debt_Issues is more pronounced for financially constrained firms, irrespective of the measure of financing constraints used. The coefficient on RE_Value $\mathrm{x} L T \_D e b t \_I s s u e s$ ranges from 0.037 and 0.039 , at $5 \%$ significance level. On the other hand, for the financially unconstrained firms, we find that the pay for responses to luck coefficient is insignificant when using both measures. These results are consistent with responses to luck being more valuable for financially constrained firms, whose managers use increases in the value of real estate assets to relax these constraints.

\subsubsection{Pay for responses to luck and corporate governance}

In this section, we explore cross-sectional variation in the level of corporate governance. Following the

literature (Bertrand and Mullainathan, 2001; Dittmar and Mahrt-Smith, 2007), we use the following measures to draw inferences about corporate governance strength: the Herfindahl index (HHI) of industry concentration and the presence of institutional blockholders. In our first test, we analyze the role played by the product market competition of the firm's industry: we construct the HHI index for each firm in our sample following Giroud and Mueller (2011). We expect to see stronger responses to luck in industries with low industry concentration. In less concentrated industries, managers have greater competitive pressure to maximize firm value, or, in other words, they have less slack to behave sub-optimally. Therefore we should expect managers in more competitive industries to more actively respond to real estate luck. In our second test, in the spirit of Core et al. (1999), we use outside blockholder ownership, defined as the ownership by external blockholders with at least $5 \%$ of the outstanding shares, as a further measure of firm governance.

Holderness (2003), among others, argue that blockholders have incentives to improve corporate management, and their presence indicates sound corporate governance. While we recognize that there are other aspects of corporate governance that may influence our setting, we focus on these measures because they are well founded in the literature and offer clear predictions for what constitutes "good" governance. 
Table 6 shows the results of pay for responses to luck in subsamples of strong and weak governed companies. We proceed by splitting our sample into high and low HHI firms (Panel A), based on the annual median value of HHI. The estimated coefficients on pay for responses to luck are positive and mostly significant in the subsample with low industry concentration (low HHI) across different measures of action (as captured by $R O A$, and RE_Sales). On the other hand, for more concentrated industries (as proxied by high $\mathrm{HHI}$ ), the results are insignificant. In Panel B, we split the sample into high and low block ownership firms, if their aggregate block ownership is above (below) the median block ownership in each year. We find that the firms with high blockholder ownership compensate executives for responses to luck, as captured by RE_Sales transactions, whereas those with low blockholder ownership do not.

Overall, the results presented in Table 6 suggest that better governed firms seem to be more likely to reward their CEOs for responding to (real estate) luck, which is consistent with the evidence of Bertrand and Mullainathan (2001). Taken together, the results presented in this section suggest that responses to luck are perceived as valuable from a shareholder's point of view.

\section{Robustness tests and discussion}

\subsection{Alternative measures of $R E_{-}$Value}

We re-estimate our baseline results using an alternative and more precise definition of a firm's real estate holdings, which accounts for accumulated depreciation of real estate. We follow Balakrishnan et al. (2014) and Chaney et al. (2012) and start with the sample of US-based Compustat firms in 1993 with nonmissing total assets. The year of 1993 was the last one in which the Securities and Exchange Commission (SEC) required that firms report the accumulated depreciation of buildings; this is also the year in which the CEO compensation information became available in Execucomp for a larger number of firms. We define real estate assets as buildings, land and improvement, and construction in progress (Compustat variables

FATB, FATC, and FATP). In essence, this is the property and plant subset of property, plant, and equipment. To compute the market value of a firm's real estate (buildings, land and improvement, and construction in progress), we measure the ratio of the accumulated depreciation of buildings (in 1993) to the historic cost of buildings, which gives us the relative proportion of the original value of a building that has been depreciated. Based on a depreciable life of 40 years (Chaney et al., 2012), we compute the average age of buildings for each firm. We infer the market value of a firm's real estate assets for each year (RE_Value_CST) in the sample period (1993 to 2016) by inflating their historical cost with MSA-level 
residential real estate inflation after 1975 and CPI inflation before $1975 .{ }^{23}$ Using this approach gives us a smaller sample, resulting in a dataset of around 5,000 observations (when we combine the firms active in 1993 with the Execucomp data), relative to our main approach described in Table 2.

Panel A in Table 7 presents the results of re-estimating the baseline regressions, using the RE_Value_CST measure of a firm's real estate holdings. Results of estimating pay for luck using Equation 1, shown in Column 1, confirm our finding that there is a positive association between CEO pay and the value of a firm's real estate holdings, further suggesting the presence of pay for (real estate) luck. The estimated coefficient of 0.012 is positive and significant at $10 \%$ level. Columns 2 to 4 show results of estimating

Equation 3 for different proxies for CEO actions. The estimated coefficients of $\beta_{2}$, on the interaction of CEO action proxies and RE_Value_CST are positive and significant at common significance levels in most specifications, with the exception of LT_Debt_Issues. In sum, the results in this section suggest that CEOs are rewarded for (real estate) luck and for responses to luck, irrespective of the computation of the value of the firm's real estate holdings.

\subsection{Geographical location of firms' real estate holdings and time-varying real estate exposure}

In the main analysis, we assume that the majority of a firm's real estate holdings are located in the same MSA as its headquarters, and we measure exposure to real estate markets using real estate holdings of the firm in 1992, which is prior to our estimation period. To address a potential concern that a firm's geographic footprint extends beyond the location of its headquarters and that exposure to real estate markets can be time-varying, we re-estimate our main results using a more granular measure of a firm's real estate holdings, which accounts for the location of firm's real estate assets across all states. We run our baseline specification using a state-weighted HPI for each firm based on its real estate holdings across the United States. Since Compustat does not contain data on the location of each piece of firm's real estate holdings, we test the validity of previous results by using state-level data on firms' operations obtained from García and Norli (2012), who extract state name counts from annual reports filed with the SEC on Form 10-K. The authors parse out all 10-Ks filed with the SEC from 1994 through 2008, which gives them information on firm real estate holdings, such as factories, warehouses, and sales offices. This procedure yields a count of the number of times each 10-K mentions a U.S. state name. Based on the state name counts, we construct a relative exposure of each firm to the state-level real estate market, as captured by state-level house price indices HPI.

\footnotetext{
${ }^{23}$ For firms with missing book value of real estate assets in 1993, we assign a book value of 0 in 1993 if they have a 0 book value of real estate assets in 1994.
} 
In this test, we follow the empirical strategy of Cunat et al. (2018), whereby HPI is not measured at the MSA level, where the company's headquarters is located, but is now calculated as a weighted average of the state-level HPIs in which the firm operates. The relative weights are based on the time-varying firm exposure to that state's real estate market obtained using García and Norli (2012) data. In this procedure, we construct measures of time-varying firm-level real estate values that account for the different weights that each location represents in the firm's overall business and construct firm-specific real estate price indices that aggregate prices across all the locations where a firm operates. Although this test helps address the measurement issues mentioned above, it introduces the concern that time-varying real estate exposure measures can be confounded with CEO's actions.

Results from replicating the tests of Tables 2 and 3 with this revised measure of real estate market values are shown in Panel B of Table 7. The results are consistent in significance and almost two times larger in the case of RE_Sales and LT_Debt_Issues than in our baseline analysis. We find evidence of pay for luck as well as evidence of pay for responses to luck.

\subsection{Measuring responses to luck}

Our identification strategy relies on the fact that, under US GAAP, a firm's accounting performance is unrelated to real estate market dynamics, unless the CEO responds to those dynamics in some way. The interaction term using one of our action variables, $R O A$, captures the sensitivity of CEO compensation to accounting performance that relates to changes in real estate values. This identification can be compromised by measurement error concerns, which we discuss in this section.

The first is the idea that the manager's optimal response to a real estate price change can be no action at all. For instance, the optimal response to an increase in prices might not be to sell and realize the capital gain but instead to hold onto the property, if prices are expected to increase even more in the future. In such cases, this "no action" response is captured by market performance but not by accounting performance.

Thus the observed sensitivity of compensation to responses to luck is underestimated.

Although unlikely, there may also be instances where accounting performance is linked to real estate prices, irrespective of responses. This is the case when real estate property is accounted for as investment property or as an asset available for sale. In these cases, real estate assets can be marked-to-market. We address this concern in two ways. First, in all our tests, we focus only on real estate property used in the

firm's operations and accounted for in property, plant, and equipment to estimate the sensitivity of compensation to responses to luck. These assets are not marked-to-market, and therefore the interaction term of $R O A$ with $R E_{-}$Value will be nonzero only if there is managerial response to real estate prices. 
By excluding investment property, again we are providing a lower bound for the coefficient of responses to luck. Note that CEOs can also respond to real estate prices by buying or selling property that is not for the use of the company but for investment purposes. However, it is also not clear whether investing in real estate assets for investment purposes is an optimal action given that this does not belong to the business operations of a nonreal-estate company (non-REIT). These cases are extremely rare: only four firm-year observations in our entire sample have such investment assets on their balance sheets.

Note as well that the pay for action that is measured is limited to firms that retain assets over the sample period. Since the real estate exposure measure is captured in 1992, if a CEO reacts to an increase in real estate by conducting for instance an SLB transaction, the manager is less able to react to a second increase in real estate prices. ${ }^{24}$

Overall, our estimated coefficients represent a lower bound for the true sensitivity of compensation to responses to luck. Both issues discussed above suggest that our coefficient is underestimated due to "no actions" not being captured and actions over investment property also being ignored.

\subsection{Endogeneity concerns}

There are two potential sources of endogeneity in our analysis. The first is that real estate prices might not be exogenous to the performance of firms and hence CEO compensation. That is, there might be an unobservable variable (e.g., an increase in demand or an influx of new firms to the region) that drives both location-specific real estate prices and CEO compensation, which would in turn affect our results. The second concern relates to the real estate ownership decision: firms more likely to own their real estate may also be more likely to compensate their CEOs for responses to luck.

To address the first concern, the omitted variable bias, we follow the instrumental variable approach of Cvijanović (2014) and Chaney et al. (2012). To capture the variation in the market value of a firm's real estate assets $R E_{-} V_{\text {Value }}, t$, we inflate the market value of its real estate holdings in 1992 with a growth in MSA-level residential (land) price index from 1992 to year $t, H P I_{m, t}$, as instrumented by interacting local land supply elasticity with aggregate real estate prices. The instrument in the first-stage regression is land supply inelasticity interacted with the growth in aggregate U.S. real estate prices from 1992 to year $t$, as measured by the S\&P/Case-Shiller U.S. National Home Price Index, and RE_Value $i_{1,1992}$, a measure of the market value of a firm's real estate assets in 1992, as shown in the following first-stage specification:

\footnotetext{
${ }^{24}$ Jennings et al. (2020) raise a related issue regarding measurement error among the control variables in the context of models with high dimensional fixed effects. Considering that our set of control variables consists mostly of accounting items, this is arguably a minor concern.
} 


$$
\begin{gathered}
H P I_{m, t}=\beta_{1} P_{t}^{\mathrm{US}} e_{0}^{m}+\beta_{2} P_{t}^{\mathrm{US}} e_{0}^{m} R E_{-} \text {Value } e_{i, 1992}^{m}+\sum_{x} \beta_{X} X_{i, t}+\gamma_{i, c}+\delta_{j, t}+\varepsilon_{c, i, t} \\
\text { RE_Value }_{i, t}^{m}=\beta_{1} P_{t}^{\mathrm{US}} e_{0}^{m}+\beta_{2} P_{t}^{\mathrm{US}} e_{0}^{m} R E_{-} \text {Value } e_{i, 1992}^{m}+\sum_{x} \beta_{X} X_{i, t}+\gamma_{i, c}+\delta_{j, t}+\varepsilon_{c, i, t},
\end{gathered}
$$

where $P_{t}^{\mathrm{US}}$ denotes the growth in S\&P/Case-Shiller U.S. House Price index from 1992 to year $t, e_{0}^{m}$ denotes land supply elasticity in MSA $m$, and $\mathrm{HPI}_{t, m}$ denotes the growth in the house price index in MSA $m$ from 1992 to year $t$. As in Equation 1, $X_{i, t}$ are firm and CEO-specific controls as defined in Section 3, and we include firm-CEO fixed effects, $\gamma_{i, c}$ and industry-year fixed effects, $\delta_{j, t}$.

We then use the predicted $R E_{-} V a l u e_{i, t}$ and MSA real estate prices $H P I_{m, t}$ from the first stage in our tests with compensation as the dependent variable, as specified in Equations 1 and 3, with the same fixed effects structure and control variables as used in Table 3.

The results of the first-stage regression are shown in Table F1 of Appendix F. As expected, the interaction of housing supply elasticity and the Case-Schiller index has a positive and statistically significant coefficient at the $1 \%$ confidence level (0.007) when used to instrument for $H P I_{m, t}$. Importantly, its interaction with $R E_{-} V_{a l u e_{i, 1992}}$ has a positive and statistically significant coefficient at the $1 \%$ confidence level (0.008) when used to instrument for $R E_{-} V a l u e_{i, t}$. A high value of the associated F-statistic (36.69) suggests that the chosen IV does not suffer from the weak instrument problem.

Our identification assumes that the elasticity of the land supply affects CEO compensation of real-estate owning firms only through its effect on real estate values. The exclusion restriction will be violated if land supply elasticity (interacted with a measure of demand for real estate, as captured by national real estate prices, and with a measure of firm-level real estate holdings) is correlated with CEO compensation for reasons other than real estate price growth. While we cannot test the exclusion restriction explicitly, the robustness of our findings to a comprehensive series of rigorous control variables and rich fixed effects structure partially mitigates this concern. Similar approaches have also been used extensively in the literature (Chaney et al., 2012; Cvijanović, 2014; Mian and Sufi, 2011; Adelino et al., 2015). ${ }^{25}$ The second potential source of endogeneity is that firms that are more likely to own real estate are also more sensitive to local demand shocks. Thus finding that CEOs are compensated for real estate changes could reflect the board's attempt to compensate the CEO for responses to demand shocks. To address this

\footnotetext{
${ }^{25}$ In a recent critique, Davidoff (2016) argues that land supply elasticity is not a good instrument for house prices, as it is not useful for comparisons across MSAs (and as such will produce biased estimates). However, he notes that identification strategy such as the one used here, which includes the interactions of HPI with firm characteristics, will not suffer from the bias. Furthermore, his critique does not apply to comparisons between real-estate-owning and nonreal-estate-owning firms that operate within the same MSA, as we do here and throughout the paper.
} 
concern, we follow the standard procedure in the literature (Chaney et al., 2012) and further include interactions between firms' initial characteristics and the HPI: in particular, we include five quintiles of firm age, firm size, and ROA as well as two-digit SIC-industry and MSA dummies. The results of these second-stage regressions are shown in Panel C in Table 7. Overall, we find significant evidence of pay for luck and significant pay for responses to luck. The estimates found using this setting are similar to those in Table 3.

To provide additional evidence related to the second concern, that firms that own their real estate may also be more likely to compensate their CEOs for responses to luck, we run a propensity-score-matching test, where we match firms into treatment and control groups by their real estate holdings in 1992, their industry, and location. The first-stage regression is a probit regression where the independent variable corresponds to the treatment variable (action) and the independent variables correspond to the real estate exposure (RE_Value), industry indicators, and MSA indicators. The treatment is defined using each of the action variables as previously defined: $R O A, R E \_S a l e s$ and $L T \_D e b t \_I s s u e s$ interacted with $R E \_V a l u e$. The treatment indicator equals one when the value of the action variable is above the sample median and zero

otherwise. Controls are matched with replacement, and we use the single nearest-neighbor matching algorithm. Results are shown in Table 8. We find a positive treatment effect on CEO compensation across the different action variables. The average treatment effect on the treated ranges from 0.027 to 0.064 and is

always statistically significant at $1 \%$. Because our dependent variable is the logarithm of pay, these estimates represent percentage differences between treatment and control groups. For instance, for firms in the treatment group defined with ROA (firms for which ROA interacted with $R E \_V a l u e$ is above median), there is a 6.4 percentage point compensation premium when compared to firms in the control group. This result is consistent with CEOs being rewarded for responses to luck.

\subsection{Types of news}

In this subsection, we explore how our results vary with the types of real estate luck. In the spirit of Balakrishnan et al. (2014), we split our sample into firm-years in which the yearly change in real estate prices was above (below) the median change in our sample, which serves as a proxy for good (bad) real estate luck. We then re-estimate our regressions separately for years with above (below) the median change in the MSA price index. Further, we analyze the effect of large changes in real estate values, by re-estimating our regressions using only firm-year observations for which the yearly changes in MSA real estate prices (HPI) are in the top quartile of our sample. The results of these tests are presented in Table 9. Overall and when considering ROA and LT_Debt_Issues, our results are driven by positive real estate luck 
(changes in HPI above the median), and they also seem to be driven by large changes in real estate prices (changes in HPI in the top quartile). ${ }^{26}$ Interestingly, managers are also compensated for responding to below median changes in HPI when it comes to RE_Sales but not when responding to above median changes. As selling real estate assets, including headquarters, is a strategic decision for firms, we conjecture that real estate prices are not the only factor to be considered. As an example, Ljungqvist and Smolyansky (2018) suggest that state corporate income taxes can also affect decisions to relocate headquarters.

\section{Conclusion}

We use variation in real estate values as a measure of luck to test whether CEOs are paid for exogenous factors outside their control (luck) and for responding to lucky events (action). To identify CEO actions, we propose a novel empirical strategy that relies on the different exposure of firms to changes in real estate values and on the fact that market and accounting performance do not reflect changes in the value of real estate in the same way. While stock market returns should promptly reflect any changes in the value of real estate assets of the firm, accounting returns should not, unless some action is taken by the manager. When we explore this difference, we find that CEOs are rewarded for their responses to luck, such as their sales of real estate or issuance of debt to take advantage of increased collateral value. We find that firms that are more financially constrained are the ones that reward CEOs for action, suggesting that the CEO's response to the luck is more valuable for these firms. While evidence of pay for luck only occurs through equity pay, CEOs seem to be compensated for action mostly using cash and in well governed firms.

Our results provide consistent evidence of pay for action or response to luck. Nonetheless, they are subject to the common caveats in the literature that studies real estate value dynamics. First, our sample is subject to a survivorship bias, since we measure exposure to real estate changes at the beginning of the sample

period, to alleviate concerns that exposure is endogenous. Second, although a firm's headquarters is typically one of its largest real estate holdings, it is likely not its only holding. To the extent that firms have significant amounts of their real estate property in states other than of their headquarters, the change in the value of those real estate assets can be an omitted variable introducing noise in our results. We perform a robustness test using a smaller sample size for which we can identify the location of each of the firm's real estate assets and obtain similar results. This test also allows us to construct a time-varying measure of a firm's real estate exposure. Third, following Chaney et al. (2012), we rely on the residential price index to proxy for changes in commercial real estate property values, as that information is not readily available. Both are highly correlated. We also show that the results are robust to doing a propensity-score match and

\footnotetext{
${ }^{26}$ In Appendix G we find similar results for SLBs.
} 
to exploring whether pay for action occurs when there is good real estate luck (i.e., yearly changes in MSA real estate prices in the top quartile or above the median value of our sample).

This paper brings a new perspective on the debate over pay for luck. Using our setting, we can identify

CEOs' responses to luck and show that they are rewarded for these responses, which are arguably optimal from the point of view of the shareholders. 


\section{Table 1. Descriptive Statistics}

Panel A presents summary statistics for CEO compensation and firm characteristics. The sample consists of all firms in Execucomp and Compustat for which Real Estate Assets data and HPI data is available for the years $1992-2016$ inclusive. HPI denotes CBSA-level house prices obtained from the Federal Housing Finance Association's (FHFA) database. All variables are winsorized at the 1st and 99th percentile values. Variables are defined in Appendix A. Panel $B$ reports the pairwise Pearson (Spearman) correlation coefficients with respect to the main variables of interest in the lower (upper) diagonal. *Indicates significance at the $1 \%$ level.

\begin{tabular}{lrrrrrr}
\hline \multicolumn{1}{c}{ Panel A } & $\mathrm{N}$ & mean & \multicolumn{1}{c}{$\mathrm{sd}$} & $\mathrm{p} 25$ & $\mathrm{p} 50$ & $\mathrm{p} 75$ \\
\hline Total Comp & 14,838 & 5,348 & 9,097 & 1,415 & 3,118 & 6,540 \\
Ln Total Comp & 14,838 & 2.073 & 0.134 & 1.982 & 2.085 & 2.173 \\
Cash Comp & 14,658 & 2,217 & 3,006 & 808 & 1,439 & 2,616 \\
Equity Comp & 14,658 & 3,132 & 7,898 & 300 & 1,371 & 3,808 \\
Assets & 14,838 & 8,695 & 25,985 & 579 & 1,760 & 5,950 \\
Log(Assets) & 14,838 & 7.574 & 1.698 & 6.361 & 7.473 & 8.691 \\
MVE & 14,838 & 5,944 & 9,552 & 570 & 1,703 & 5,896 \\
Tobin's Q & 14,838 & 1.958 & 1.419 & 1.204 & 1.548 & 2.195 \\
ROA & 14,838 & 0.051 & 0.153 & 0.029 & 0.064 & 0.104 \\
EBIT & 14,838 & 563 & 963 & 42 & 147 & 549 \\
Return & 14,838 & 0.160 & 0.528 & -0.126 & 0.100 & 0.341 \\
Volatility & 14,838 & 0.026 & 0.013 & 0.017 & 0.023 & 0.032 \\
RE_Assets & 14,838 & 0.304 & 0.232 & 0.120 & 0.235 & 0.453 \\
RE_Value & 14,838 & 0.371 & 0.381 & 0.133 & 0.231 & 0.444 \\
RE_Sales & 14,838 & 0.006 & 0.026 & 0.000 & 0.000 & 0.002 \\
LT_Debt_Issues & 14,771 & 0.024 & 0.114 & -0.016 & 0.000 & 0.035 \\
SLB & 12,681 & 0.002 & 0.043 & 0.000 & 0.000 & 0.000 \\
CEO Age & 14,838 & 56.24 & 7.12 & 52.00 & 56.00 & 61.00 \\
HPI & 14,838 & 1.691 & 0.553 & 1.225 & 1.607 & 2.034 \\
Firm Age & 14,286 & 25.66 & 13.65 & 14.15 & 24.66 & 36.94 \\
Div Payout Ratio & 14,816 & 0.463 & 0.639 & 0.000 & 0.178 & 0.727 \\
Whited Wu & 14,752 & 0.111 & 0.799 & -0.214 & 0.140 & 0.448 \\
HHI & 14,838 & 0.066 & 0.065 & 0.032 & 0.044 & 0.072 \\
Block Ownership & 12,487 & 0.196 & 0.125 & 0.100 & 0.181 & 0.274 \\
\hline
\end{tabular}

\begin{tabular}{|c|c|c|c|c|c|c|c|c|c|c|c|}
\hline & Panel B & 1 & 2 & 3 & 4 & 5 & 6 & 7 & 8 & 9 & 10 \\
\hline 1 & Ln Total Comp & 1 & $0.200^{*}$ & $0.123^{*}$ & $0.220^{*}$ & $-0.087^{*}$ & $-0.074^{*}$ & $0.040^{*}$ & $0.042^{*}$ & 0.012 & 0.012 \\
\hline 2 & RE Value & $0.179^{*}$ & 1 & $-0.119^{*}$ & $0.559^{*}$ & -0.004 & $0.060^{*}$ & 0.013 & $0.029 *$ & 0.001 & 0.001 \\
\hline 3 & ROA & $0.123^{*}$ & $-0.025^{*}$ & 1 & $0.641^{*}$ & $-0.053^{*}$ & $-0.057^{*}$ & $-0.025^{*}$ & $-0.031^{*}$ & -0.015 & -0.015 \\
\hline 4 & RE_Value $x$ ROA & $0.187^{*}$ & $0.391^{*}$ & $0.559^{*}$ & 1 & $-0.087^{*}$ & $-0.050^{*}$ & 0.008 & 0.017 & -0.011 & -0.011 \\
\hline 5 & RE_Sales & $-0.041^{*}$ & $0.077^{*}$ & $-0.185^{*}$ & $-0.108^{*}$ & 1 & $0.992^{*}$ & $-0.060^{*}$ & $-0.064^{*}$ & 0.007 & 0.007 \\
\hline 6 & RE_Value $x$ RE_Sales & 0.012 & $0.181^{*}$ & $-0.161^{*}$ & $-0.069^{*}$ & $0.784^{*}$ & 1 & $-0.059^{*}$ & $-0.064^{*}$ & 0.007 & 0.007 \\
\hline 7 & LT_Debt_Issues & $0.022^{*}$ & 0.010 & -0.006 & -0.010 & $-0.050^{*}$ & $-0.033^{*}$ & 1 & $0.968^{*}$ & -0.012 & -0.012 \\
\hline 8 & RE_Value $x$ LT_Debt_Issues & $0.041^{*}$ & $0.182^{*}$ & -0.000 & $0.052^{*}$ & $-0.032^{*}$ & -0.012 & $0.740^{*}$ & 1 & -0.011 & -0.011 \\
\hline 9 & SLB & 0.012 & -0.003 & -0.011 & -0.008 & 0.005 & 0.000 & -0.011 & -0.005 & 1 & $1.000^{*}$ \\
\hline 10 & RE_Value $\times$ SLB & 0.011 & 0.017 & -0.003 & 0.012 & 0.004 & 0.003 & -0.004 & 0.001 & $0.783^{*}$ & 1 \\
\hline
\end{tabular}




\section{Table 2. Pay for Luck - Total Compensation}

This table examines the role of real estate luck in CEO compensation. It presents estimates of OLS regressions of the logarithm of CEO total compensation on the market value of a firm's real estate assets RE_Value and other CEO and firm level control variables. Independent variable RE_Value is defined in Section 3.2.1. HPI denotes CBSA-level house prices obtained from the Federal Housing Finance Association's (FHFA) database. The sample consists of all firms in Execucomp and Compustat for which Real Estate Assets data and HPI data is available for the years $1992-2016$ inclusive. All variables are winsorized at the $1^{\text {th }}$ and $99^{\text {th }}$ percentile values. Remaining variables are defined in the Appendix A. Asterisks indicate statistical significance at the $1 \%\left({ }^{* * *}\right), 5 \%\left({ }^{* *}\right)$, or $10 \%\left({ }^{*}\right)$ level.

\begin{tabular}{lcc}
\hline & $(1)$ & $(2)$ \\
\hline RE_Value & $0.065^{* * *}$ & $0.028^{* *}$ \\
ROA & {$[4.311]$} & {$[2.015]$} \\
& $0.026^{* * *}$ & $0.021^{* * *}$ \\
Stock Return & {$[3.953]$} & {$[3.733]$} \\
& $0.009^{* * *}$ & $0.008^{* * *}$ \\
ROA(t-1) & {$[3.834]$} & {$[3.511]$} \\
& $0.031^{* * *}$ & $0.024^{* * *}$ \\
Stock Return(t-1) & {$[5.184]$} & {$[4.210]$} \\
& $0.014^{* * *}$ & $0.014^{* * *}$ \\
Log(Assets) & {$[7.556]$} & {$[7.535]$} \\
& $0.042^{* * *}$ & $0.042^{* * *}$ \\
HPI(t-1) & {$[16.697]$} & {$[13.828]$} \\
& $-0.020^{* * *}$ & -0.011 \\
Tobin's Q & {$[-3.124]$} & {$[-1.567]$} \\
& $0.012^{* * *}$ & $0.011^{* * *}$ \\
Volatility & {$[8.520]$} & {$[7.130]$} \\
& -0.057 & -0.094 \\
CEO Age & {$[-0.331]$} & {$[-0.547]$} \\
& $0.007^{* *}$ & $0.007^{* *}$ \\
CEO Age Squared & {$[2.503]$} & {$[2.543]$} \\
& $-0.000^{* *}$ & $-0.000^{* *}$ \\
& {$[-2.319]$} & {$[-2.077]$} \\
& & \\
Observations & & \\
R-squared & 14,838 & 14,706 \\
& 0.811 & 0.829 \\
\hline CEO-Firm FE & & \\
Yr FE & $\mathrm{Y}$ & $\mathrm{Y}$ \\
Ind-Yr FE & $\mathrm{Y}$ & $\mathrm{N}$ \\
Cluster MSA \& Year & $\mathrm{Y}$ & $\mathrm{Y}$ \\
\hline
\end{tabular}




\section{Table 3. Pay for Action - Total Compensation}

This table examines the role of responses to real estate luck in CEO compensation. It presents estimates of OLS regressions of the logarithm of CEO total compensation on the market value of a firm's real estate assets RE_Value interacted with four CEO action variables: ROA, RE_Sales, $L T \_D e b t \_I s s u e s$ and SLB, and other CEO and firm level control variables. Independent variable RE_Value and CEO action variables are defined in Section 3.2.1 and in Appendix A. HPI denotes CBSA-level house prices obtained from the Federal Housing Finance Association's (FHFA) database. Coefficient estimates are obtained using CEO-firm and industry-year fixed effects. All variables are winsorized at the $1^{\text {th }}$ and $99^{\text {th }}$ percentile values. Remaining control variables are defined in the Appendix A. Asterisks indicate statistical significance at the $1 \%\left(^{* * *}\right), 5 \%\left({ }^{* *}\right)$, or $10 \%\left(^{*}\right)$ level.

\begin{tabular}{|c|c|c|c|c|c|c|c|}
\hline & (1) & (2) & (3) & (4) & (5) & (6) & $(7)$ \\
\hline RE_Value & $\begin{array}{c}0.026^{*} \\
{[1.907]}\end{array}$ & $\begin{array}{c}0.027^{*} \\
{[1.939]}\end{array}$ & $\begin{array}{c}0.027^{*} \\
{[1.941]}\end{array}$ & $\begin{array}{l}0.027^{* *} \\
{[2.002]}\end{array}$ & $\begin{array}{l}0.027^{* *} \\
{[2.010]}\end{array}$ & $\begin{array}{c}0.039^{* * *} \\
{[2.637]}\end{array}$ & $\begin{array}{c}0.039^{* * *} \\
{[2.650]}\end{array}$ \\
\hline RE_Value $x$ ROA & $\begin{array}{l}0.105^{* *} \\
{[2.062]}\end{array}$ & & & & & & \\
\hline RE_Value x RE_Sales & & $\begin{array}{c}0.085 \\
{[1.565]}\end{array}$ & $\begin{array}{c}0.056^{* * *} \\
{[2.965]}\end{array}$ & & & & \\
\hline RE_Sales & & $\begin{array}{c}-0.034 \\
{[-0.538]}\end{array}$ & & & & & \\
\hline RE_Value x LT_Debt_Issues & & & & $\begin{array}{c}0.037^{* * *} \\
{[2.257]}\end{array}$ & $\begin{array}{c}0.017 \\
{[1.596]}\end{array}$ & & \\
\hline LT_Debt_Issues & & & & $\begin{array}{c}-0.010 \\
{[-1.111]}\end{array}$ & & & \\
\hline RE_Value x SLB & & & & & & $\begin{array}{c}-0.022 \\
{[-0.742]}\end{array}$ & $\begin{array}{c}0.027 \\
{[1.351]}\end{array}$ \\
\hline SLB & & & & & & $\begin{array}{l}0.028^{* *} \\
{[1.999]}\end{array}$ & \\
\hline $\mathrm{ROA}$ & $\begin{array}{c}0.009 \\
{[1.071]}\end{array}$ & $\begin{array}{c}0.022^{* * *} \\
{[3.673]}\end{array}$ & $\begin{array}{c}0.023^{* * *} \\
{[3.776]}\end{array}$ & $\begin{array}{c}0.023^{* * *} \\
{[4.721]}\end{array}$ & $\begin{array}{c}0.021^{* * *} \\
{[3.725]}\end{array}$ & $\begin{array}{l}0.018^{* *} \\
{[2.838]}\end{array}$ & $\begin{array}{l}0.018^{* *} \\
{[2.841]}\end{array}$ \\
\hline Stock Return & $\begin{array}{c}0.008^{* * *} \\
{[3.373]}\end{array}$ & $\begin{array}{c}0.008^{* * *} \\
{[3.515]}\end{array}$ & $\begin{array}{c}0.009^{* * *} \\
{[3.538]}\end{array}$ & $\begin{array}{c}0.008^{* * *} \\
{[3.583]}\end{array}$ & $\begin{array}{c}0.008^{* * *} \\
{[3.497]}\end{array}$ & $\begin{array}{c}0.008^{* * *} \\
{[3.200]}\end{array}$ & $\begin{array}{c}0.008^{* * *} \\
{[3.200]}\end{array}$ \\
\hline $\operatorname{ROA}(\mathrm{t}-1)$ & $\begin{array}{c}0.023^{* * *} \\
{[4.333]}\end{array}$ & $\begin{array}{c}0.024^{* * *} \\
{[4.055]}\end{array}$ & $\begin{array}{c}0.024^{* * *} \\
{[4.269]}\end{array}$ & $\begin{array}{c}0.023^{* * *} \\
{[3.548]}\end{array}$ & $\begin{array}{c}0.024^{* * *} \\
{[4.271]}\end{array}$ & $\begin{array}{c}0.025^{* * *} \\
{[3.662]}\end{array}$ & $\begin{array}{c}0.025^{* * *} \\
{[3.674]}\end{array}$ \\
\hline Stock Return(t-1) & $\begin{array}{c}0.013^{* * *} \\
{[7.167]}\end{array}$ & $\begin{array}{c}0.014^{* * *} \\
{[7.217]}\end{array}$ & $\begin{array}{c}0.014^{* * *} \\
{[7.504]}\end{array}$ & $\begin{array}{c}0.014^{* * *} \\
{[7.810]}\end{array}$ & $\begin{array}{c}0.013^{* * *} \\
{[7.521]}\end{array}$ & $\begin{array}{c}0.014^{* * *} \\
{[7.634]}\end{array}$ & $\begin{array}{c}0.014^{* * *} \\
{[7.577]}\end{array}$ \\
\hline Log(Assets) & $\begin{array}{l}0.042^{* * *} \\
{[13.928]}\end{array}$ & $\begin{array}{l}0.042^{* * *} \\
{[14.278]}\end{array}$ & $\begin{array}{l}0.042^{* * *} \\
{[14.130]}\end{array}$ & $\begin{array}{l}0.041^{* * *} \\
{[12.598]}\end{array}$ & $\begin{array}{l}0.041^{* * *} \\
{[13.101]}\end{array}$ & $\begin{array}{l}0.041^{* * *} \\
{[11.334]}\end{array}$ & $\begin{array}{l}0.041^{* * *} \\
{[11.285]}\end{array}$ \\
\hline $\mathrm{HPI}(\mathrm{t}-1)$ & $\begin{array}{c}-0.011 \\
{[-1.672]}\end{array}$ & $\begin{array}{c}-0.011 \\
{[-1.568]}\end{array}$ & $\begin{array}{c}-0.011 \\
{[-1.572]}\end{array}$ & $\begin{array}{c}-0.011 \\
{[-1.578]}\end{array}$ & $\begin{array}{c}-0.011 \\
{[-1.569]}\end{array}$ & $\begin{array}{l}-0.015^{*} \\
{[-1.919]}\end{array}$ & $\begin{array}{l}-0.015^{*} \\
{[-1.938]}\end{array}$ \\
\hline Tobin's Q & $\begin{array}{c}0.011^{* * *} \\
{[7.087]}\end{array}$ & $\begin{array}{c}0.011^{* * *} \\
{[7.177]}\end{array}$ & $\begin{array}{c}0.011^{* * *} \\
{[7.120]}\end{array}$ & $\begin{array}{c}0.011^{* * *} \\
{[7.180]}\end{array}$ & $\begin{array}{c}0.011^{* * *} \\
{[7.089]}\end{array}$ & $\begin{array}{c}0.011^{* * *} \\
{[5.991]}\end{array}$ & $\begin{array}{c}0.011^{* * *} \\
{[5.982]}\end{array}$ \\
\hline Volatility & $\begin{array}{c}-0.092 \\
{[-0.539]}\end{array}$ & $\begin{array}{c}-0.098 \\
{[-0.571]}\end{array}$ & $\begin{array}{c}-0.098 \\
{[-0.569]}\end{array}$ & $\begin{array}{c}-0.097 \\
{[-0.589]}\end{array}$ & $\begin{array}{c}-0.092 \\
{[-0.541]}\end{array}$ & $\begin{array}{c}-0.070 \\
{[-0.386]}\end{array}$ & $\begin{array}{c}-0.070 \\
{[-0.386]}\end{array}$ \\
\hline CEO Age & $\begin{array}{l}0.007^{* *} \\
{[2.453]}\end{array}$ & $\begin{array}{l}0.007^{* *} \\
{[2.595]}\end{array}$ & $\begin{array}{l}0.007^{* *} \\
{[2.542]}\end{array}$ & $\begin{array}{l}0.006^{* *} \\
{[2.373]}\end{array}$ & $\begin{array}{l}0.007^{* *} \\
{[2.545]}\end{array}$ & $\begin{array}{c}0.006^{*} \\
{[1.797]}\end{array}$ & $\begin{array}{c}0.006^{*} \\
{[1.805]}\end{array}$ \\
\hline CEO Age Squared & $\begin{array}{l}-0.000^{*} \\
{[-2.009]}\end{array}$ & $\begin{array}{l}-0.000^{* *} \\
{[-2.122]}\end{array}$ & $\begin{array}{l}-0.000^{* *} \\
{[-2.074]}\end{array}$ & $\begin{array}{l}-0.000^{*} \\
{[-1.913]}\end{array}$ & $\begin{array}{l}-0.000^{* *} \\
{[-2.082]}\end{array}$ & $\begin{array}{c}-0.000 \\
{[-1.361]}\end{array}$ & $\begin{array}{c}-0.000 \\
{[-1.367]}\end{array}$ \\
\hline $\begin{array}{l}\text { Observations } \\
\text { R-squared }\end{array}$ & $\begin{array}{c}14,706 \\
0.829\end{array}$ & $\begin{array}{c}14,706 \\
0.829\end{array}$ & $\begin{array}{c}14,706 \\
0.829\end{array}$ & $\begin{array}{c}14,706 \\
0.829\end{array}$ & $\begin{array}{c}14,706 \\
0.829\end{array}$ & $\begin{array}{c}11,913 \\
0.818\end{array}$ & $\begin{array}{c}11,913 \\
0.818\end{array}$ \\
\hline CEO-Firm FE & $\mathrm{Y}$ & $\mathrm{Y}$ & $\mathrm{Y}$ & $\mathrm{Y}$ & $\mathrm{Y}$ & $\mathrm{Y}$ & $\mathrm{Y}$ \\
\hline Ind-Yr FE & $\mathrm{Y}$ & $\mathrm{Y}$ & $\mathrm{Y}$ & Y & Y & $\mathrm{Y}$ & $\mathrm{Y}$ \\
\hline Cluster MSA \& Year & Y & Y & $\mathrm{Y}$ & Y & Y & $\mathrm{Y}$ & $\mathrm{Y}$ \\
\hline
\end{tabular}




\section{Table 4. Pay for Action - Components of Pay}

This table examines responses to real estate luck by components of CEO compensation. Columns 1 through 7 (8 through 14 ) present estimates of OLS regressions of the logarithm of cash compensation (the logarithm of equity compensation) on the market value of a firm's real estate assets $R E$ Value interacted with four CEO action variables: ROA, RE_Sales, LT_Debt_Issues and $S L B$, and other CEO and firm level control variables. Independent variable $R E \_V a l u e$ and CEO action variables are defined in Section 3.2.1 and in Appendix A. HPI denotes CBSA-level house prices obtained from the Federal Housing Finance Association's (FHFA) database. All specifications include CEO-firm and industry-year fixed effects. All variables are winsorized at the $1^{\text {th }}$ and $99^{\text {th }}$ percentile values. Remaining control variables are defined in the Appendix A. Asterisks indicate statistical significance at the $1 \%\left({ }^{* * *}\right), 5 \%\left(^{* *}\right)$, or $10 \%\left({ }^{*}\right)$ level.

\begin{tabular}{|c|c|c|c|c|c|c|c|c|c|c|c|c|c|c|}
\hline & (1) & (2) & (3) & (4) & (5) & (6) & (7) & (8) & (9) & (10) & (11) & (12) & (13) & (14) \\
\hline & \multicolumn{7}{|c|}{ Log Cash Comp } & \multicolumn{7}{|c|}{ Log (1+ Equity Comp) } \\
\hline RE_Value & $\begin{array}{c}-0.213 \\
{[-1.666]}\end{array}$ & $\begin{array}{c}-0.187 \\
{[-1.421]}\end{array}$ & $\begin{array}{c}-0.190 \\
{[-1.437]}\end{array}$ & $\begin{array}{l}-0.170 \\
-1.2911\end{array}$ & $\begin{array}{c}-0.179 \\
{[-1.366]}\end{array}$ & $\begin{array}{c}-0.114 \\
{[-0.896]}\end{array}$ & $\begin{array}{c}-0.114 \\
{[-0.9011}\end{array}$ & $1.096^{* *}$ & $1.089^{* *}$ & $\begin{array}{l}1.115^{* *} \\
2.649]\end{array}$ & $\begin{array}{l}1.065^{* *} \\
2588]\end{array}$ & $\begin{array}{l}1.070^{* *} \\
{[2669]}\end{array}$ & $1.262^{* *}$ & $1.264^{* *}$ \\
\hline RE_Value $x$ ROA & $1.444^{* * *}$ & & & & & & & 0.130 & & & & & & \\
\hline RE_Value $\times$ RE_Sales & & $\begin{array}{c}0.467 \\
{[1.495]}\end{array}$ & $\begin{array}{c}0.636^{* * *} \\
{[3.257]}\end{array}$ & & & & & & $\begin{array}{c}0.606 \\
{[0.287]}\end{array}$ & $\begin{array}{c}-1.160 \\
{[-1.093]}\end{array}$ & & & & \\
\hline RE_Sales & & $\begin{array}{c}0.202 \\
{[0.638]}\end{array}$ & & & & & & & $\begin{array}{c}-2.107 \\
{[-1.312]}\end{array}$ & & & & & \\
\hline RE_Value $x$ LT_Debt_Issues & & & & $\begin{array}{c}0.063 \\
{[0.378]}\end{array}$ & $\begin{array}{c}-0.046 \\
{[-0.547]}\end{array}$ & & & & & & $\begin{array}{c}0.881 \\
{[1.418]}\end{array}$ & $\begin{array}{l}0.863^{* *} \\
{[2.322]}\end{array}$ & & \\
\hline LT_Debt_Issues & & & & $\begin{array}{c}-0.060 \\
{[-0.908]}\end{array}$ & & & & & & & $\begin{array}{c}0.013 \\
{[0.044]}\end{array}$ & & & \\
\hline RE Value $\times$ SLB & & & & & & $\begin{array}{l}0.614^{* *} \\
{[2.679]}\end{array}$ & $\begin{array}{l}0.436^{*} \\
{[1.754]}\end{array}$ & & & & & & $\begin{array}{c}-2.594 \\
{[-1.217]}\end{array}$ & $\begin{array}{r}-1.713 \\
{[-1.457]}\end{array}$ \\
\hline SLB & & & & & & $\begin{array}{c}-0.103 \\
{[-0.625]}\end{array}$ & & & & & & & $\begin{array}{c}0.508 \\
{[0.577]}\end{array}$ & \\
\hline ROA & $\begin{array}{c}-0.045 \\
{[-0.746]}\end{array}$ & $\begin{array}{c}0.141^{* * *} \\
{[3.129]}\end{array}$ & $\begin{array}{c}0.140^{* * *} \\
{[3.091]}\end{array}$ & $\begin{array}{c}0.133^{* * *} \\
{[2.867]}\end{array}$ & $\begin{array}{l}0.121^{* *} \\
{[2.686]}\end{array}$ & $\begin{array}{l}0.117^{* *} \\
{[2.382]}\end{array}$ & $\begin{array}{l}0.118^{* *} \\
{[2.430]}\end{array}$ & $\begin{array}{l}0.703^{* *} \\
{[2.462]}\end{array}$ & $\begin{array}{l}0.668^{* *} \\
{[2.660]}\end{array}$ & $\begin{array}{l}0.684^{* *} \\
{[2.700]}\end{array}$ & $\begin{array}{c}0.756^{* * *} \\
{[3.049]}\end{array}$ & $\begin{array}{c}0.721^{* * *} \\
{[2.920]}\end{array}$ & $\begin{array}{c}0.616^{*} \\
{[2.105]}\end{array}$ & $\begin{array}{l}0.614^{*} \\
{[2.104]}\end{array}$ \\
\hline Stock Return & $\begin{array}{c}0.137^{* * *} \\
{[8.148]}\end{array}$ & $\begin{array}{l}0.142^{* * *} \\
{[8.421]}\end{array}$ & $\begin{array}{c}0.142^{* * *} \\
{[8.463]}\end{array}$ & $\begin{array}{c}0.142^{* * *} \\
{[8.642]}\end{array}$ & $\begin{array}{c}0.141^{* * *} \\
{[8.406]}\end{array}$ & $\begin{array}{c}0.136^{* * *} \\
{[7.767]}\end{array}$ & $\begin{array}{c}0.136^{* * *} \\
{[7.762]}\end{array}$ & $\begin{array}{c}0.071 \\
{[1.610]}\end{array}$ & $\begin{array}{c}0.068 \\
{[1.445]}\end{array}$ & $\begin{array}{c}0.071 \\
{[1.582]}\end{array}$ & $\begin{array}{c}0.067 \\
{[1.482]}\end{array}$ & $\begin{array}{c}0.071 \\
{[1.585]}\end{array}$ & $\begin{array}{c}0.051 \\
{[0.978]}\end{array}$ & $\begin{array}{c}0.051 \\
{[0.973]}\end{array}$ \\
\hline $\operatorname{ROA}(\mathrm{t}-1)$ & $\begin{array}{c}0.005 \\
{[0.117]}\end{array}$ & $\begin{array}{c}0.019 \\
{[0.419]}\end{array}$ & $\begin{array}{c}0.018 \\
{[0.406]}\end{array}$ & $\begin{array}{c}0.003 \\
{[0.066]}\end{array}$ & $\begin{array}{c}0.016 \\
{[0.361]}\end{array}$ & $\begin{array}{c}0.010 \\
{[0.224]}\end{array}$ & $\begin{array}{c}0.010 \\
{[0.232]}\end{array}$ & $\begin{array}{l}0.581^{* *} \\
{[2.311]}\end{array}$ & $\begin{array}{l}0.571^{* *} \\
{[2.224]}\end{array}$ & $\begin{array}{l}0.578^{* *} \\
{[2.275]}\end{array}$ & $\begin{array}{l}0.585^{* *} \\
{[2.232]}\end{array}$ & $\begin{array}{l}0.587^{* *} \\
{[2.358]}\end{array}$ & $\begin{array}{c}0.435^{*} \\
{[1.833]}\end{array}$ & $\begin{array}{c}0.435^{*} \\
{[1.899]}\end{array}$ \\
\hline Stock Return(t-1) & $\begin{array}{c}0.098^{* * *} \\
{[8.874]}\end{array}$ & $\begin{array}{c}0.103^{* * * *} \\
{[9.625]}\end{array}$ & $\begin{array}{c}0.103^{* * *} \\
{[9.557]}\end{array}$ & $\begin{array}{c}0.104^{* * * *} \\
{[9.490]}\end{array}$ & $\begin{array}{c}0.102^{* * *} \\
{[9.357]}\end{array}$ & $\begin{array}{c}0.098^{* * * *} \\
{[9.308]}\end{array}$ & $\begin{array}{c}0.098^{* * *} \\
{[9.317]}\end{array}$ & $\begin{array}{c}0.088 \\
{[1.482]}\end{array}$ & $\begin{array}{c}0.085 \\
{[1.455]}\end{array}$ & $\begin{array}{c}0.088 \\
{[1.490]}\end{array}$ & $\begin{array}{c}0.086 \\
{[1.466]}\end{array}$ & $\begin{array}{c}0.087 \\
{[1.500]}\end{array}$ & $\begin{array}{c}0.079 \\
{[1.239]}\end{array}$ & $\begin{array}{c}0.079 \\
{[1.233]}\end{array}$ \\
\hline Log(Assets) & $\begin{array}{c}0.167^{* * *} \\
{[8.447]}\end{array}$ & $\begin{array}{c}0.163^{* * * *} \\
{[7.822]}\end{array}$ & $\begin{array}{c}0.163^{* * *} \\
{[7.855]}\end{array}$ & $\begin{array}{c}0.163^{* * *} \\
{[8.469]}\end{array}$ & $\begin{array}{c}0.162^{* * *} \\
{[8.099]}\end{array}$ & $\begin{array}{c}0.150^{* * *} \\
{[5.829]}\end{array}$ & $\begin{array}{c}0.150^{* * *} \\
{[5.842]}\end{array}$ & $\begin{array}{c}0.608^{* * *} \\
{[6.579]}\end{array}$ & $\begin{array}{c}0.599^{* * *} \\
{[6.523]}\end{array}$ & $\begin{array}{c}0.604^{* * *} \\
{[6.550]}\end{array}$ & $\begin{array}{c}0.570^{* * *} \\
{[6.243]}\end{array}$ & $\begin{array}{c}0.581^{* * *} \\
{[6.041]}\end{array}$ & $\begin{array}{c}0.575^{* * *} \\
{[5.660]}\end{array}$ & $\begin{array}{c}0.575^{* *} \\
{[5.653]}\end{array}$ \\
\hline HPI(t-1) & $\begin{array}{l}-0.051^{*} \\
{[-1.773]}\end{array}$ & $\begin{array}{c}-0.044 \\
{[-1.452]}\end{array}$ & $\begin{array}{c}-0.043 \\
{[-1.433]}\end{array}$ & $\begin{array}{c}-0.042 \\
{[-1.346]}\end{array}$ & $\begin{array}{c}-0.043 \\
{[-1.404]}\end{array}$ & $\begin{array}{l}-0.074^{* *} \\
{[-2.254]}\end{array}$ & $\begin{array}{c}-0.073^{* * *} \\
{[-2.239]}\end{array}$ & $\begin{array}{c}-0.074 \\
{[-0.358]}\end{array}$ & $\begin{array}{c}-0.066 \\
{[-0.325]}\end{array}$ & $\begin{array}{c}-0.072 \\
{[-0.351]}\end{array}$ & $\begin{array}{c}-0.077 \\
{[-0.372]}\end{array}$ & $\begin{array}{c}-0.074 \\
{[-0.361]}\end{array}$ & $\begin{array}{c}-0.109 \\
{[-0.406]}\end{array}$ & $\begin{array}{c}-0.111 \\
{[-0.411]}\end{array}$ \\
\hline Tobin's Q & $\begin{array}{l}0.023^{* *} \\
{[2.431]}\end{array}$ & $\begin{array}{l}0.023^{* *} \\
{[2.477]}\end{array}$ & $\begin{array}{l}0.023^{* *} \\
{[2.472]}\end{array}$ & $\begin{array}{l}0.023^{* *} \\
{[2.479]}\end{array}$ & $\begin{array}{l}0.024^{* *} \\
{[2.489]}\end{array}$ & $\begin{array}{l}0.022^{* *} \\
{[2.138]}\end{array}$ & $\begin{array}{l}0.022^{* *} \\
{[2.161]}\end{array}$ & $\begin{array}{c}0.150^{* * *} \\
{[4.540]}\end{array}$ & $\begin{array}{c}0.153^{* * * *} \\
{[4.405]}\end{array}$ & $\begin{array}{l}0.151^{* * *} \\
{[4.480]}\end{array}$ & $\begin{array}{l}0.153^{* * *} \\
{[4.466]}\end{array}$ & $\begin{array}{l}0.151^{* * *} \\
{[4.478]}\end{array}$ & $\begin{array}{l}0.155^{* * * *} \\
{[4.085]}\end{array}$ & $\begin{array}{l}0.155^{* *} \\
{[4.112]}\end{array}$ \\
\hline Volatility & $\begin{array}{l}-1.347 \\
{[-1.567]}\end{array}$ & $\begin{array}{c}-1.421 \\
{[-1.634]}\end{array}$ & $\begin{array}{c}-1.421 \\
{[-1.640]}\end{array}$ & $\begin{array}{c}-1.395 \\
{[-1.681]}\end{array}$ & $\begin{array}{c}-1.375 \\
{[-1.599]}\end{array}$ & $\begin{array}{c}-1.296 \\
{[-1.487]}\end{array}$ & $\begin{array}{l}-1.297 \\
{[-1.486]}\end{array}$ & $\begin{array}{c}-10.563^{* *} \\
{[-2.074]}\end{array}$ & $\begin{array}{l}-10.476^{*} \\
{[-2.067]}\end{array}$ & $\begin{array}{l}-10.475^{*} \\
{[-2.060]}\end{array}$ & $\begin{array}{l}-10.506^{*} \\
{[-2.063]}\end{array}$ & $\begin{array}{l}-10.501^{*} \\
{[-2.072]}\end{array}$ & $\begin{array}{l}-10.616^{*} \\
{[-1.958]}\end{array}$ & $\begin{array}{r}-10.614 \\
{[-1.974]}\end{array}$ \\
\hline CEO Age & $\begin{array}{c}0.029 \\
{[1.518]}\end{array}$ & $\begin{array}{c}0.030 \\
{[1.639]}\end{array}$ & $\begin{array}{c}0.030 \\
{[1.644]}\end{array}$ & $\begin{array}{c}0.024 \\
{[1.357]}\end{array}$ & $\begin{array}{c}0.030 \\
{[1.648]}\end{array}$ & $\begin{array}{c}0.026 \\
{[1.173]}\end{array}$ & $\begin{array}{c}0.025 \\
{[1.169]}\end{array}$ & $\begin{array}{c}0.226^{* * * *} \\
{[3.550]}\end{array}$ & $\begin{array}{c}0.229^{* * * *} \\
{[3.617]}\end{array}$ & $\begin{array}{c}0.226^{* * * *} \\
{[3.554]}\end{array}$ & $\begin{array}{c}0.225^{* * *} \\
{[3.610]}\end{array}$ & $\begin{array}{c}0.228^{* * * *} \\
{[3.589]}\end{array}$ & $\begin{array}{l}0.192^{* *} \\
{[2.753]}\end{array}$ & $\begin{array}{l}0.192^{* *} \\
{[2.757]}\end{array}$ \\
\hline CEO Age Squared & $\begin{array}{c}-0.000 \\
{[-1.421]}\end{array}$ & $\begin{array}{c}-0.000 \\
{[-1.524]}\end{array}$ & $\begin{array}{c}-0.000 \\
{[-1.535]}\end{array}$ & $\begin{array}{c}-0.000 \\
{[-1.169]}\end{array}$ & $\begin{array}{c}-0.000 \\
{[-1.543]}\end{array}$ & $\begin{array}{c}-0.000 \\
{[-0.968]}\end{array}$ & $\begin{array}{c}-0.000 \\
{[-0.965]}\end{array}$ & $\begin{array}{c}-0.001^{* * *} \\
{[-2.945]}\end{array}$ & $\begin{array}{c}-0.001^{* * *} \\
{[-2.963]}\end{array}$ & $\begin{array}{c}-0.001^{* * *} \\
{[-2.942]}\end{array}$ & $\begin{array}{c}-0.001^{* * *} \\
{[-3.002]}\end{array}$ & $\begin{array}{c}-0.001^{* * *} \\
{[-2.993]}\end{array}$ & $\begin{array}{l}-0.001^{* *} \\
{[-2.176]}\end{array}$ & $\begin{array}{l}-0.001^{* *} \\
{[-2.179]}\end{array}$ \\
\hline Observations & 14,705 & 14,705 & 14,705 & 14,705 & 14,705 & 11,912 & 11,912 & 14,706 & 14,706 & 14,706 & 14,706 & 14,706 & 11,913 & 11,913 \\
\hline R-squared & 0.854 & 0.853 & 0.853 & 0.854 & 0.853 & 0.854 & 0.854 & 0.596 & 0.596 & 0.596 & 0.595 & 0.596 & 0.574 & 0.574 \\
\hline CEO-Firm FE & $\mathrm{Y}$ & $\mathrm{Y}$ & Y & $\mathrm{Y}$ & $\mathrm{Y}$ & $\mathrm{Y}$ & $\mathrm{Y}$ & $\mathrm{Y}$ & $\mathrm{Y}$ & $\mathrm{Y}$ & $\mathrm{Y}$ & $\mathrm{Y}$ & Y & Y \\
\hline Ind-Yr FE & $\mathrm{Y}$ & $\mathrm{Y}$ & $\mathrm{Y}$ & $\mathrm{Y}$ & $\mathrm{Y}$ & $\mathrm{Y}$ & $\mathrm{Y}$ & $\mathrm{Y}$ & $\mathrm{Y}$ & $\mathrm{Y}$ & $\mathrm{Y}$ & $\mathrm{Y}$ & $\mathrm{Y}$ & $\mathrm{Y}$ \\
\hline Cluster MSA \& Year & $\mathrm{Y}$ & $\mathrm{Y}$ & $\mathrm{Y}$ & $\mathrm{Y}$ & $\mathrm{Y}$ & $\mathrm{Y}$ & $\mathrm{Y}$ & $\mathrm{Y}$ & $\mathrm{Y}$ & $\mathrm{Y}$ & $\mathrm{Y}$ & $\mathrm{Y}$ & $\mathrm{Y}$ & $\mathrm{Y}$ \\
\hline
\end{tabular}




\section{Table 5. Pay for Action - Financial Constraints}

This table examines the role of responses to real estate luck in CEO compensation by level of financing constraints across companies. It presents estimates of OLS regressions of the logarithm of CEO total compensation on the market value of a firm's real estate assets RE_Value interacted with LT_Debt_Issues, and other CEO and firm level control variables. Independent variable $R E_{-}$Value and CEO action variable $L T_{-}$Debt_Issues are defined in Section 3.2.1 and in Appendix A. HPI denotes CBSA-level house prices obtained from the Federal Housing Finance Association's (FHFA) database. We classify firms with (without) financial constraints if their Whited-Wu (W-W) Index is above (below) the median for the year or if their dividend payout is below (above) the median for the year. HPI denotes CBSA-level house prices obtained from the Federal Housing Finance Association's (FHFA) database. All specifications include CEO-firm and industryyear fixed effects. All specifications include all control variables used in Table 3, but for brevity, their coefficients are suppressed (Controls include: Stock Return (t), Log(Assets), HPI (t-1), Tobin's Q, Volatility, ROA(t-1), Stock Return (t-1), CEO Age, CEO Age Squared). All variables are winsorized at the $1^{\text {th }}$ and $99^{\text {th }}$ percentile values. Remaining control variables and financial constraints indices are defined in the Appendix A. Asterisks indicate statistical significance at the $1 \%\left({ }^{* * *}\right), 5 \%\left({ }^{* *}\right)$, or $10 \%\left({ }^{*}\right)$ level.

\begin{tabular}{lccccc}
\hline & $(1)$ & $(2)$ & & $(3)$ & $(4)$ \\
\hline & \multicolumn{2}{c}{ Financial Constraints } & & \multicolumn{2}{c}{ No Financial Constraints } \\
\cline { 2 - 3 } \cline { 6 - 7 } RE_Value & Div Payout & $\mathrm{W}-\mathrm{W}$ & & Div Payout & $\mathrm{W}-\mathrm{W}$ \\
& 0.031 & 0.019 & & 0.026 & 0.028 \\
RE_Value x LT_Debt_Issues & {$[1.171]$} & {$[1.213]$} & & {$[1.248]$} & {$[1.058]$} \\
& $0.039^{* *}$ & $0.037^{* *}$ & & 0.018 & -0.001 \\
& {$[2.456]$} & {$[2.326]$} & & {$[1.010]$} & {$[-0.047]$} \\
Observations & & & & & \\
R-squared & 6,773 & 6,557 & & 7,379 & 6,638 \\
& 0.800 & 0.852 & & 0.885 & 0.859 \\
Other Controls & & & & & \\
CEO-Firm FE & $\mathrm{Y}$ & $\mathrm{Y}$ & & $\mathrm{Y}$ & $\mathrm{Y}$ \\
Ind-Yr FE & $\mathrm{Y}$ & $\mathrm{Y}$ & & $\mathrm{Y}$ & $\mathrm{Y}$ \\
Cluster MSA \& Year & $\mathrm{Y}$ & $\mathrm{Y}$ & & $\mathrm{Y}$ & $\mathrm{Y}$ \\
\hline
\end{tabular}




\section{Table 6. Pay for Action - Corporate Governance}

This table examines the role of responses to real estate luck in CEO compensation by level of corporate governance across companies. It presents estimates of OLS regressions of the logarithm of CEO total compensation on the market value of a firm's real estate assets $R E \_$Value interacted with four CEO action variables: ROA, RE_Sales, and LT_Debt_Issues, and other CEO and firm level control variables. Independent variable $R E \_$Value and CEO action variables are defined in Section 3.2.1 and in Appendix A. HPI denotes CBSA-level house prices obtained from the Federal Housing Finance Association's (FHFA) database. Panels are differentiated by whether firms have below / above median Herfindahl Index (HHI) in each year (Panel A), or high/low blockholder ownership (Panel B). High (Low) blockholder ownership firms are those above (below) the median blockownership in each year. All specifications include CEO-firm and industryyear fixed effects. All specifications include all control variables used in Table 3, but for brevity, their coefficients are suppressed (Controls include: Stock Return(t), Log(Assets), HPI(t-1), Tobin's Q, Volatility, ROA(t-1), Stock Return(t-1), CEO Age, CEO Age Squared). All variables are winsorized at the $1^{\text {th }}$ and $99^{\text {th }}$ percentile values. Remaining control variables and corporate governance indices are defined in the Appendix A. Asterisks indicate statistical significance at the $1 \%\left({ }^{* * *}\right), 5 \%\left({ }^{* *}\right)$, or $10 \%\left({ }^{*}\right)$ level.

\begin{tabular}{|c|c|c|c|c|c|c|}
\hline Panel A & (1) & (2) & (3) & (4) & (5) & (6) \\
\hline & \multicolumn{3}{|c|}{ High Competition $=$ Low $\mathrm{HHI}$} & \multicolumn{3}{|c|}{ Low Competition $=$ High HHI } \\
\hline RE_Value & $\begin{array}{c}0.044 \\
{[1.670]}\end{array}$ & $\begin{array}{c}0.043 \\
{[1.629]}\end{array}$ & $\begin{array}{c}0.044 \\
{[1.670]}\end{array}$ & $\begin{array}{c}0.007 \\
{[0.461]}\end{array}$ & $\begin{array}{c}0.009 \\
{[0.589]}\end{array}$ & $\begin{array}{c}0.008 \\
{[0.533]}\end{array}$ \\
\hline RE_Value $\times$ ROA & $\begin{array}{c}0.115^{*} \\
{[1.911]}\end{array}$ & & & $\begin{array}{c}0.097 \\
{[1.259]}\end{array}$ & & \\
\hline RE_Value $x$ RE_Sales & & $\begin{array}{l}0.047^{* *} \\
{[2.175]}\end{array}$ & & & $\begin{array}{c}0.055 \\
{[0.657]}\end{array}$ & \\
\hline RE_Value x LT_Debt_Issues & & & $\begin{array}{c}0.014 \\
{[0.908]}\end{array}$ & & & $\begin{array}{c}0.030 \\
{[1.222]}\end{array}$ \\
\hline Observations & 7,258 & 7,258 & 7,258 & 7,134 & 7,134 & 7,134 \\
\hline R-squared & 0.828 & 0.828 & 0.828 & 0.853 & 0.853 & 0.853 \\
\hline Other Controls & $\mathrm{Y}$ & $\mathrm{Y}$ & Y & Y & Y & Y \\
\hline CEO-Firm FE & $\mathrm{Y}$ & $\mathrm{Y}$ & Y & Y & $\mathrm{Y}$ & Y \\
\hline Ind-Yr FE & Y & $\mathrm{Y}$ & Y & Y & Y & Y \\
\hline Cluster MSA \& Year & Y & $\mathrm{Y}$ & Y & Y & Y & Y \\
\hline \multirow[t]{2}{*}{ Panel B } & (1) & (2) & (3) & (4) & (5) & (6) \\
\hline & \multicolumn{3}{|c|}{ High Block Ownership = High Gov. } & \multicolumn{3}{|c|}{ Low Block Ownership = Low Gov. } \\
\hline RE_Value & $\begin{array}{c}0.042 \\
{[1.476]}\end{array}$ & $\begin{array}{c}0.043 \\
{[1.479]}\end{array}$ & $\begin{array}{c}0.043 \\
{[1.483]}\end{array}$ & $\begin{array}{c}0.028 \\
{[0.971]}\end{array}$ & $\begin{array}{c}0.027 \\
{[0.971]}\end{array}$ & $\begin{array}{c}0.028 \\
{[1.027]}\end{array}$ \\
\hline RE_Value $\times$ ROA & $\begin{array}{c}0.071 \\
{[0.641]}\end{array}$ & & & $\begin{array}{c}0.079 \\
{[1.366]}\end{array}$ & & \\
\hline RE_Value $x$ RE_Sales & & $\begin{array}{c}0.122^{* * *} \\
{[3.412]}\end{array}$ & & & $\begin{array}{c}0.048 \\
{[1.454]}\end{array}$ & \\
\hline RE_Value x LT_Debt_Issues & & & $\begin{array}{c}-0.001 \\
{[-0.085]}\end{array}$ & & & $\begin{array}{c}0.014 \\
{[0.630]}\end{array}$ \\
\hline Observations & 4,735 & 4,735 & 4,735 & 5,095 & 5,095 & 5,095 \\
\hline R-squared & 0.828 & 0.828 & 0.827 & 0.894 & 0.894 & 0.894 \\
\hline Other Controls & $\mathrm{Y}$ & $\mathrm{Y}$ & $\mathrm{Y}$ & $Y$ & $Y$ & $Y$ \\
\hline CEO-Firm FE & Y & $\mathrm{Y}$ & Y & $\mathrm{Y}$ & $\mathrm{Y}$ & Y \\
\hline Ind-Yr FE & Y & $\mathrm{Y}$ & Y & $\mathrm{Y}$ & $\mathrm{Y}$ & Y \\
\hline Cluster MSA \& Year & Y & $\mathrm{Y}$ & Y & Y & Y & Y \\
\hline
\end{tabular}




\section{Table 7. Robustness Tests}

This table presents estimates of OLS regressions of the logarithm of CEO total compensation on the market value of a firm's real estate assets interacted with four CEO action variables: ROA, RE_Sales, and LT_Debt_Issues, and other CEO and firm level control variables. Panel A: Independent variable RE_Value_CST is defined following Balakrishnan et al. (2014), and Chaney et al. (2012), as in Section 5.1. Panel B: Independent variable RE_Value is defined in Section 5.2. Computation of RE_Value in this table is based on the geographical location of all of firms' real estate assets, using data sample provided by García and Norli (2012), covering time period of 1994 through 2008. State-weighted HPI for each firm is based on its real estate holdings across the U.S. instead of only using the real estate holdings in the state of its headquarters. Relative state-weights are calculated in each year based on the firm's real estate assets in each state. Panel C: This panel presents the results of the second stage regressions following the IV approach of Cvijanović (2014), as described in Section 5.4. Results of the first stage regressions are shown in Appendix F, Table F1. Independent variable $R E \_$Value is defined in Section 5.4. Both first and second stage specifications include all control variables used in Table 3. We also control for the firm ownership decision, by including interactions between firms' initial characteristics and the HPI: we include five quintiles of: firm age, firm size, ROA, as well as two-digit SIC industry dummies and MSA indicators. Action variables are defined in Section 3.2.1 and in Appendix A. All specifications in all panels include all control variables used in Table 3, but for brevity, their coefficients are suppressed (Controls include: Stock Return ( $\mathrm{t}$ ), Log(Assets), HPI(t-1), Tobin's Q, Volatility, ROA(t-1), Stock Return(t-1), CEO Age, CEO Age Squared). All variables are winsorized at the $1^{\text {th }}$ and $99^{\text {th }}$ percentile values. Remaining control variables are defined in the Appendix A. Standard errors are clustered at the MSA and year level. Asterisks indicate statistical significance at the $1 \%\left({ }^{* * *}\right), 5 \%\left({ }^{* *}\right)$, or $10 \%$ (*) level.

\begin{tabular}{|c|c|c|c|c|}
\hline Action Measure & (1) & $\begin{array}{l}(2) \\
\text { ROA }\end{array}$ & $\begin{array}{c}(3) \\
\text { RE_Sales }\end{array}$ & $\begin{array}{c}(4) \\
\text { LT_Debt_Issues }\end{array}$ \\
\hline \multicolumn{5}{|c|}{ Panel A: Alternative Measure RE Value using Chaney et al (2012) Approach } \\
\hline RE_Value_CST & $\begin{array}{l}0.012^{*} \\
{[1.842]}\end{array}$ & $\begin{array}{c}0.011 \\
{[1.509]}\end{array}$ & $\begin{array}{l}0.014^{* *} \\
{[2.180]}\end{array}$ & $\begin{array}{l}0.012^{*} \\
{[1.756]}\end{array}$ \\
\hline RE_Value_CST $x$ Action Measure & & $\begin{array}{c}0.012^{* * *} \\
{[3.911]}\end{array}$ & $\begin{array}{c}0.016^{* * *} \\
{[3.519]}\end{array}$ & $\begin{array}{c}0.001 \\
{[0.913]}\end{array}$ \\
\hline $\begin{array}{l}\text { Observations } \\
\text { R-squared }\end{array}$ & $\begin{array}{l}4,998 \\
0.817\end{array}$ & $\begin{array}{l}4,998 \\
0.818\end{array}$ & $\begin{array}{l}4,998 \\
0.818\end{array}$ & $\begin{array}{l}4,998 \\
0.818\end{array}$ \\
\hline \multicolumn{5}{|c|}{ Panel B: Geographical Footprint and Time-Varying Real Estate Exposure } \\
\hline RE_Value & $\begin{array}{l}0.077^{* *} \\
{[2.744]}\end{array}$ & $\begin{array}{l}0.066^{* *} \\
{[2.478]}\end{array}$ & $\begin{array}{l}0.077^{* *} \\
{[2.779]}\end{array}$ & $\begin{array}{l}0.076^{* *} \\
{[2.542]}\end{array}$ \\
\hline RE_Value $x$ Action Measure & & $\begin{array}{l}0.024^{* *} \\
{[2.570]}\end{array}$ & $\begin{array}{l}0.096^{*} \\
{[1.884]}\end{array}$ & $\begin{array}{l}0.060^{*} \\
{[1.657]}\end{array}$ \\
\hline $\begin{array}{l}\text { Observations } \\
\text { R-squared }\end{array}$ & $\begin{array}{l}8,319 \\
0.813\end{array}$ & $\begin{array}{l}8,319 \\
0.814\end{array}$ & $\begin{array}{l}8,319 \\
0.813\end{array}$ & $\begin{array}{l}8,288 \\
0.814\end{array}$ \\
\hline \multicolumn{5}{|c|}{ Panel C: Exogenous Variation in Real Estate Prices - IV } \\
\hline RE_Value & $\begin{array}{l}0.023^{*} \\
{[1.674]}\end{array}$ & $\begin{array}{c}0.017 \\
{[1.259]}\end{array}$ & $\begin{array}{c}0.022 \\
{[1.133]}\end{array}$ & $\begin{array}{c}0.001 \\
{[0.031]}\end{array}$ \\
\hline RE_Value $x$ Action Measure & & $\begin{array}{l}0.057^{* *} \\
{[2.196]}\end{array}$ & $\begin{array}{l}0.119^{* *} \\
{[2.137]}\end{array}$ & $\begin{array}{l}0.003^{*} \\
{[1.700]}\end{array}$ \\
\hline Observations & 12,364 & 12,364 & 12,315 & 12,364 \\
\hline R-squared & 0.082 & 0.083 & 0.100 & 0.083 \\
\hline Controls & $\mathrm{Y}$ & $\mathrm{Y}$ & $\mathrm{Y}$ & $\mathrm{Y}$ \\
\hline CEO-Firm FE & Y & Y & $\mathrm{Y}$ & Y \\
\hline Ind-Yr FE & Y & Y & $\mathrm{Y}$ & Y \\
\hline Cluster MSA \& Year & Y & Y & Y & Y \\
\hline
\end{tabular}




\section{Table 8. Propensity Score Matching Analysis}

This table presents the average treatment effect estimates of action variables on CEO compensation making use of propensity score matching. Matching variables include industry, the amount of real estate holdings in 1992 and MSA; Treatment dummy is equal to one if the value of action variable interacted with the value of real estate (for $R O A$, $R E \_S a l e s$ and LT_Debt_Issues) is above the median. All variables are winsorized at the $1^{\text {th }}$ and $99^{\text {th }}$ percentile values. $\mathrm{N}$ corresponds to the number of matched observations. Asterisks indicate statistical significance at the $1 \%\left({ }^{* * *}\right), 5 \%\left({ }^{* *}\right)$, or $10 \%\left({ }^{*}\right)$ level.

\begin{tabular}{lccc}
\hline & ROA & RE_Sales & LT_Debt_Issues \\
\hline Treated group & 2.094 & 2.059 & 2.087 \\
Control group & 2.030 & 2.032 & 2.023 \\
Difference & $0.064^{* * *}$ & $0.027^{* * *}$ & $0.064^{* * *}$ \\
& {$[8.78]$} & {$[3.21]$} & {$[12.61]$} \\
\hline $\mathrm{N}$ & 14,261 & 14,458 & 14,564 \\
\hline
\end{tabular}




\section{Table 9. Types of News}

This table examines a series of sensitivity analyses of our baseline results with respect to the extent and type of real estate changes, following Balakrishnan et al. (2014). All specifications include all control variables used in Table 3, but for brevity, their coefficients are suppressed (Controls include: Stock Return (t), Log(Assets), predicted HPI ( $\mathrm{t}-1)$ from the first stage, Tobin's Q, Volatility, ROA(t-1), Stock Return ( $\mathrm{t}-1)$, CEO Age, CEO Age Squared). All variables are winsorized at the $1^{\text {th }}$ and $99^{\text {th }}$ percentile values. Remaining control variables are defined in the Appendix A. Asterisks indicate statistical significance at the $1 \%\left({ }^{* *}\right), 5 \%(* *)$, or $10 \%(*)$ level.

\begin{tabular}{|c|c|c|c|c|c|c|c|c|c|}
\hline & (1) & (2) & (3) & (4) & (5) & (6) & (7) & (8) & (9) \\
\hline & \multicolumn{3}{|c|}{ CHG HPI Above Median } & \multicolumn{3}{|c|}{ CHG HPI Below Median } & \multicolumn{3}{|c|}{ CHG HPI Top Quartile } \\
\hline RE_Value & $\begin{array}{l}0.049^{*} \\
{[1.946]}\end{array}$ & $\begin{array}{l}0.055^{* *} \\
{[2.181]}\end{array}$ & $\begin{array}{l}0.053^{* *} \\
{[2.116]}\end{array}$ & $\begin{array}{c}0.018 \\
{[0.588]}\end{array}$ & $\begin{array}{c}0.016 \\
{[0.496]}\end{array}$ & $\begin{array}{c}0.018 \\
{[0.579]}\end{array}$ & $\begin{array}{c}0.049 \\
{[1.308]}\end{array}$ & $\begin{array}{c}0.060 \\
{[1.635]}\end{array}$ & $\begin{array}{c}0.056 \\
{[1.559]}\end{array}$ \\
\hline RE_Value $\times$ ROA & $\begin{array}{l}0.199^{* *} \\
{[2.808]}\end{array}$ & & & $\begin{array}{c}-0.067 \\
{[-1.573]}\end{array}$ & & & $\begin{array}{c}0.335^{* * *} \\
{[4.211]}\end{array}$ & & \\
\hline RE_Value $\times$ RE_Sales & & $\begin{array}{c}0.016 \\
{[0.618]}\end{array}$ & & & $\begin{array}{c}0.212^{* * *} \\
{[3.685]}\end{array}$ & & & $\begin{array}{c}-0.034 \\
{[-0.544]}\end{array}$ & \\
\hline RE_Value x LT_Debt_Issues & & & $\begin{array}{c}0.044^{* * *} \\
{[5.081]}\end{array}$ & & & $\begin{array}{c}-0.016 \\
{[-0.914]}\end{array}$ & & & $\begin{array}{l}0.041^{* *} \\
{[2.237]}\end{array}$ \\
\hline Observations & 6,862 & 6,862 & 6,862 & 6,900 & 6,900 & 6,900 & 3,063 & 3,063 & 3,063 \\
\hline R-squared & 0.837 & 0.837 & 0.837 & 0.872 & 0.873 & 0.872 & 0.844 & 0.842 & 0.842 \\
\hline Other Controls & Y & $\mathrm{Y}$ & Y & $\mathrm{Y}$ & $\mathrm{Y}$ & Y & $\mathrm{Y}$ & Y & Y \\
\hline Firm-CEO FE & $\mathrm{Y}$ & $\mathrm{Y}$ & $\mathrm{Y}$ & $\mathrm{Y}$ & $\mathrm{Y}$ & $\mathrm{Y}$ & $\mathrm{Y}$ & $\mathrm{Y}$ & $\mathrm{Y}$ \\
\hline Ind-Yr FE & Y & Y & Y & Y & Y & Y & $\mathrm{Y}$ & Y & Y \\
\hline Cluster MSA \& Year & $\mathrm{Y}$ & $\mathrm{Y}$ & $\mathrm{Y}$ & $\mathrm{Y}$ & $\mathrm{Y}$ & $\mathrm{Y}$ & $\mathrm{Y}$ & $\mathrm{Y}$ & Y \\
\hline
\end{tabular}




\section{References}

Adelino, M., Schoar, A., and Severino, F. (2015). House prices, collateral, and self-employment. Journal of Financial Economics, 117(2):288-306.

Aggarwal, R. K. and Samwick, A. A. (1999). The other side of the trade-off: The impact of risk on executive compensation. Journal of Political Economy, 107(1):65-105.

Albuquerque, A. (2009). Peer firms in relative performance evaluation. Journal of Accounting and Economics, 48(1):69-89.

Albuquerque, A. M., De Franco, G., and Verdi, R. S. (2013). Peer choice in CEO compensation. Journal of Financial Economics, 108(1):160-181.

Almeida, H., Campello, M., and Weisbach, M. S. (2011). Corporate financial and investment policies when future financing is not frictionless. Journal of Corporate Finance, 17(3):675-693.

Axelson, U. and Baliga, S. (2008). Liquidity and manipulation of executive compensation schemes. The Review of Financial Studies, 22(10):3907-3939.

Axelson, U. and Bond, P. (2015). Wall street occupations. The Journal of Finance, 70(5):1949-1996.

Balakrishnan, K., Core, J. E., and Verdi, R. S. (2014). The relation between reporting quality and financing and investment: evidence from changes in financing capacity. Journal of Accounting Research, 52(1):1-36.

Bebchuk, L. A. and Fried, J. M. (2003). Executive compensation as an agency problem. Journal of Economic Perspectives, 17(3):71-92.

Bebchuk, L. A., Grinstein, Y., and Peyer, U. (2010). Lucky CEOs and lucky directors. The Journal of Finance, 65(6):2363-2401.

Ben-David, I. (2005). Company performance and leased assets in sale-and-leaseback transactions. The Journal of Equipment Lease Financing, 23(2):A1.

Bertrand, M., Duflo, E., and Mullainathan, S. (2004). How much should we trust differences-in-differences estimates? The Quarterly Journal of Economics, 119(1):249-275.

Bertrand, M. and Mullainathan, S. (1998). Is there discretion in wage setting? a test using takeover legislation. Technical report, National Bureau of Economic Research.

Bertrand, M. and Mullainathan, S. (2001). Are CEOs rewarded for luck? The ones without principals are. The Quarterly Journal of Economics, 116(3):901-932. 
Bettis, C., Bizjak, J., Coles, J., and Kalpathy, S. (2010). Stock and option grants with performance-based vesting provisions. The Review of Financial Studies, 23(10):3849-3888.

Bettis, J. C., Bizjak, J., Coles, J., and Kalpathy, S. (2018). Performance-vesting provisions in executive compensation. Journal of Accounting and Economics.

Bizjak, J. M., Lemmon, M. L., and Naveen, L. (2008). Does the use of peer groups contribute to higher pay and less efficient compensation? Journal of Financial Economics, 90(2):152-168.

Black, D., Black, E., Christensen, T., and Gee, K. (2020). Comparing non-gaap eps in earnings announcements and proxy statements. Management Science.

Cadman, B. and Carter, M. E. (2013). Compensation peer groups and their relation with ceo pay. Journal of Management Accounting Research, 26(1):57-82.

Campello, M. and Hackbarth, D. (2012). The firm-level credit multiplier. Journal of Financial Intermediation, 21(3):446-472.

Chaigneau, P., Edmans, A., and Gottlieb, D. (2014). The value of informativeness for contracting. Technical report, HEC Montreal and London Business School.

Chaney, T., Sraer, D., and Thesmar, D. (2012). The collateral channel: How real estate shocks affect corporate investment. American Economic Review, 102(6):2381-2409.

Chhaochharia, V. and Grinstein, Y. (2009). CEO Compensation and Board Oversight. Journal of Finance, 64:231-262.

Chiu, H.-H., Oxelheim, L., Wihlborg, C., and Zhang, J. (2016). Macroeconomic fluctuations as sources of luck in ceo compensation. Journal of Business Ethics, 136(2):371-384.

Conley, T., Goncalves, S., and Hansen, C. (2018). Inference with dependent data in accounting and finance applications. Journal of Accounting Research, 56(4):1139-1203.

Core, J., Guay, W., and Larcker, D. (2002). Executive equity compensation and incentives: A survey. Unpublished Working Paper.

Core, J. E., Holthausen, R. W., and Larcker, D. F. (1999). Corporate governance, chief executive officer compensation, and firm performance. Journal of Financial Economics, 51(3):371-406.

Cuñat, V., Cvijanović, D., and Yuan, K. (2018). Within-bank spillovers of real estate shocks. The Review of Corporate Finance Studies. 
Curtis, A., Li, V., and Patrick, P. H. (2021). The use of adjusted earnings in performance evaluation. Review of Accounting Studies, pages 1-33.

Cvijanović, D. (2014). Real estate prices and firm capital structure. The Review of Financial Studies, 27(9):26902735.

Davidoff, T. (2016). Supply constraints are not valid instrumental variables for home prices because they are correlated with many demand factors. Critical Finance Review, 5(2):177-206.

De Angelis, D. and Grinstein, Y. (2011). Relative performance evaluation in ceo compensation: Evidence from the 2006 disclosure rules. Johnson School Research Paper Series, (39-2010).

DeMarzo, P. M., Fishman, M. J., He, Z., and Wang, N. (2012). Dynamic agency and the q theory of investment. The Journal of Finance, 67(6):2295-2340.

Dittmar, A. and Mahrt-Smith, J. (2007). Corporate governance and the value of cash holdings. Journal of Financial Economics, 83(3):599-634.

Fahlenbrach, R. (2008). Shareholder rights, boards, and CEO compensation. Review of Finance, 13(1):81-113.

Faulkender, M. and Yang, J. (2010). Inside the black box: The role and composition of compensation peer groups. Journal of Financial Economics, 96(2):257-270.

García, D. and Norli, Ø. (2012). Geographic dispersion and stock returns. Journal of Financial Economics, 106(3):547-565.

Garvey, G. T. and Milbourn, T. T. (2006). Asymmetric benchmarking in compensation: Executives are rewarded for good luck but not penalized for bad. Journal of Financial Economics, 82(1):197-225.

Giroud, X. and Mueller, H. M. (2011). Corporate governance, product market competition, and equity prices. The Journal of Finance, 66(2):563-600.

Gong, G., Li, L. Y., and Shin, J. Y. (2011). Relative performance evaluation and related peer groups in executive compensation contracts. The Accounting Review, 86(3):1007-1043.

Gopalan, R., Milbourn, T., and Song, F. (2010a). Strategic flexibility and the optimality of pay for sector performance. The Review of Financial Studies, 23(5):2060-2098.

Gopalan, R., Milbourn, T., Song, F., and Thakor, A. (2010b). The optimal duration of executive compensation: Theory and evidence. Journal of Finance, 69:2777-2817. 
Göx, R. F. (2008). Tax incentives for inefficient executive pay and reward for luck. Review of Accounting Studies, 13(4):452-478.

Graham, J. R., Li, S., and Qiu, J. (2012). Managerial attributes and executive compensation. The Review of Financial Studies, 25(1):144-186.

Hadlock, C. J. and Pierce, J. R. (2010). New evidence on measuring financial constraints: Moving beyond the kz index. The Review of Financial Studies, 23(5):1909-1940.

Holderness, C. G. (2003). A survey of blockholders and corporate control. Economic Policy Review, 9(1).

Holmström, B. (1979). Moral hazard and observability. The Bell Journal of Economics, 10:74-91.

Jennings, J. N., Kim, J. M., Lee, J. A., and Taylor, D. J. (2020). Measurement error and bias in causal models in accounting research. Available at SSRN 3731197.

Ljungqvist, A. and Smolyansky, M. (2018). To cut or not to cut? on the impact of corporate taxes on employment and income. On the Impact of Corporate Taxes on Employment and Income (October 3, 2018).

Lobo, G. J., Neel, M., and Rhodes, A. (2018). Accounting comparability and relative performance evaluation in ceo compensation. Review of Accounting Studies, pages 1-40.

Mian, A. and Sufi, A. (2011). House prices, home equity-based borrowing, and the us household leverage crisis. American Economic Review, 101(5):2132-56.

Murphy, K. J. (1999). Executive compensation. Handbook of Labor Economics, 3:2485-2563.

Noe, T. H. and Rebello, M. J. (2011). Optimal corporate governance and compensation in a dynamic world. The Review of Financial Studies, 25(2):480-521.

Potepa, J. (2020). The treatment of special items in determining ceo cash compensation. Review of Accounting Studies, pages 1-39.

Rutherford, R. C. (1990). Empirical Evidence on Shareholder Value and the SaleâLeaseback of Corporate Real Estate. Real Estate Economics, 18(4):522-529.

Sloan, R. G. (1993). Accounting earnings and top executive compensation. Journal of Accounting and Economics, 16(1-3):55-100.

Slovin, M. B., Sushka, M. E., and Polonchek, J. A. (1990). Corporate Sale-and-Leasebacks and Shareholder Wealth. The Journal of Finance, 45(1):289-299. 
Whitby, R. (2013). Market responses to sale-and-leasebacks. Real Estate Finance, 29:2-6.

Whited, T. M. and Wu, G. (2006). Financial constraints risk. The Review of Financial Studies, 19(2):531-559. 


\section{A Appendix A.}

\section{Variable Definitions}

CEO Level Variables

Total Compensation

Cash Compensation

Equity Compensation

CEO Age

CEO Tenure

Firm Level Variables

Log MVE

LT_Debt_Issues

RE_Sales

Tobin's Q

ROA

Volatility

Stock Return

RE_Value

HPI

SLB
Total CEO pay in thousand \$, which consists of salary, bonus, value of restricted stock granted, value of options granted, long-term incentive payout, and other compensation (ExecuComp TDC1).

Salary plus bonus plus long-term incentive payout (before 2006) (ExecuComp SALARY + BONUS + LTIP) and salary plus bonus plus non equity incentive pay (after 2006) (ExecuComp SALARY + BONUS + NONEQ_INCENT) in thousand \$.

Value of restricted stock granted plus value of options granted in thousand \$ (ExecuComp RSTKGRNT + OPTION_AWARDS_BLK_VALUE before 2006 (pre adoption of FAS 123R) and STOCK_AWARDS_FV + OPTION_AWARDS_BLK_VALUE after 2006.)

Age of CEO in years (ExecuComp).

Number of years as CEO in the current position (ExecuComp).

Log of market capitalization in thousands of \$ (Compustat PRCC_F x CSHO).

Change in long-term debt in thousands of \$ (Compustat DLTT) scaled by lagged total assets (Compustat AT).

The absolute value of RE assets plus depreciation (Compustat (PPENT - PPENLS - PPENME + DP) less previous year's RE assets scaled by lagged total assets (Compustat lagged AT) if negative, otherwise zero. When this variable is zero, but the value for the sale of property (Compustat variabel SPPE) is positive, we replace it with its value scaled by lagged total assets (SPPE/lagged AT).

Sum of total assets plus market value of equity minus book value of equity divided by total assets [Compustat (AT + CSHO x PRCC_F - CEQ) / AT] .

Net income plus rental expenses multiplied by one minus income taxes scaled by pretax income divided by total assets (Compustat (NI+XRENT*(1-TXT/PI))/AT).

Annualized standard deviation of monthly stock returns (CRSP).

Annual stock return [Compustat (PRCC_F(t) / AJEX(t) + DVPSX_F(t) / AJEX(t)) / (PRCC_F(t-1) / AJEX_F(t-1))].

For a comprehensive description see Section 3.1.

Level of the House Price Index for a particular Core Based or Metropolitan Statistical Area (Federal Housing Finance Association), obtained from the Federal Housing Finance Association's (FHFA).

An identifier variable that assumes the value of one, if the firm has engaged in a sale and lease back transaction in the prior calendar year. SLB transactions are obtained from Whitby (2013) for the sample period of 1992 to 2011. 
WW

$\mathrm{HHI}$

Blockholder Ownership
The Whited-Wu Index. We calculate the WW index value for each sample firm and place firms with index values above (below) the median within the year cohort in the constrained (unsconstrained) category.

Dividends to common stockholders scaled by common shares outstanding [Compustat DVC / CSHO].

For each year in the sample, we rank firms based on their payout ratio and assign them to the financially constrained (unconstrained) groups based on whether their annual payout is below (above) the median of the annual payout distribution.

Herfindahl Hirschman Index computed as the sum of the squared market shares within an SIC2 digit industry and year.

Total ownership of blockholders, where a blockholder is defined as an outside owner of $5 \%$ or more of the total shares outstanding. 


\section{B Appendix B.}

\section{Examples of cases where SLB are explicitly mentioned when discussing CEO pay}

Example 1: TOUCHSTONE APPLIED SCIENCE ASSOCIATES, INC. Proxy Statement filled on March, 31, 2004

(bold added for emphasis)

“The Compensation Committee reviews the performance of Mr. Andrew L. Simon, the Company's Chief Executive Officer, by evaluating the achievement of the corporate and personal objectives set each year in conjunction with the Board's approval of the annual budget and the Company's strategic plan. The Committee considered the positive effects of the consummation of the disposition of the Company's discontinued operations during Fiscal 2003. Other positive achievements of the Company during Fiscal 2003 included significant growth in revenues from sales, the completion of the sale-leaseback of the Company's headquarters, and the early repayment of the Company's outstanding subordinated indebtedness. With respect to the Company's performance in Fiscal 2003, Mr. Simon was awarded a cash bonus of $\$ 50,000$ which will be paid in Fiscal 2004, and options to purchase 20,000 shares of Common Stock at $\$ 2.10$ per share, the market price at the time of the grant. In addition, Mr. Simon's base salary was modestly increased to $\$ 234,945$, from $\$ 227,000$.

The Compensation Committee believes that Fiscal 2003 was a year of solid performance by the Company, especially in a somewhat lackluster business environment. The completion of the disposition of the discontinued operations, the consummation of the sale-leaseback of the Company's headquarters and the early repayment of the Company's outstanding subordinated indebtedness combined to enable the Company to refocus its resources on the assessment products market. The results of operations for Fiscal 2003 reflected all of these positive accomplishments, and the Committee feels that the salary adjustments and incentive compensation awarded to the Chief Executive Officer and other members of senior management were appropriate, and would provide further incentive to management to strive for continued improvements in revenues and profitability. The Compensation Committee believes that the compensation program of the Company properly serves to align the interests of the management with the interests of the stockholders."

Example 2: QUIDEL CORP, Proxy Statement filled on April, 13, 2000 (bold added for emphasis) “The Chief Executive Officer's total cash compensation for the nine-month period ended December 31, 1999 was $\$ 292,300$ in base salary. No incentive compensation was awarded. Specific accomplishments that were considered by the Board and occurred under Mr. de Bruin's leadership during this period are as follows: (1) the acquisition of Metra Biosystems, Inc., a leader in the diagnosis and management of metabolic bone diseases and disorders, (2) the acquisition of a urine test strip business from Dade Behring 
Marburg GmbH which will allow for leverage of global sales, (3) the receipt of United States Food and Drug Administration clearance and initiated marketing of the QuickVue Influenza test, a point-of-care diagnostic test that provides accurate diagnosis of Influenza A and B in ten minutes, (4) the sale and leaseback of the corporate headquarters facility that provided the cash to reduce the debt incurred in the Metra and Dade Behring acquisitions, (5) the implementation of a new enterprise resource planning business operating system which is expected to allow the operations of the business to become more efficient and provide a strong platform for business growth, (6) the increase of production capacity to meet increased demand for products, and (7) the implementation of our long-range strategic mission to drive future product development and partnerships. The Corporate earnings goal for this period was not met." 


\section{Appendix C}

\section{C.1 Estimating pay for luck and pay for action using Bertrand and Mullainathan (2001) approach}

In this section we estimate pay for luck and pay for action following Bertrand and Mullainathan (2001) empirical setting. The standard approach by Bertrand and Mullainathan (2001) consists of estimating the sensitivity of $\mathrm{CEO}$ compensation to changes in firm performance driven by luck, using exogenous determinants of firm performance such as oil prices or exchange rates. However, when estimating the sensitivity of compensation to luck in this framework, one cannot disentangle the sensitivity of pay to luck from the sensitivity of pay to reactions to luck (action). As Bertrand and Mullainathan (2001) point out, finding pay for luck in their setting can still be consistent with the possibility that "boards tie pay to luck to motivate CEOs to forecast or respond to luck shocks."

Making use of the accounting treatment of real estate assets described in Section 2.2 allows us to do just that: given that any shocks to the value of a firm's real estate should only be reflected on the firm's balance sheet if there was an action in response to the shock, we are able to disentangle the sensitivity of CEO pay to luck (measured by the market value of its real estate assets) from the sensitivity of pay to reactions to luck. Bertrand and Mullainathan (2001) run a two stage model where in the first stage firm performance is explained by luck and, in the second stage, performance driven by luck explains CEO pay. In their setting accounting performance and market performance are used as substitutes to show evidence of pay for luck because both measures are similarly affected by changes in oil prices, which is their main luck variable. In our setting, accounting performance does not correlate with real estate prices unless there is action. For this reason, we use market performance to estimate pay for luck and action, and ROA to estimate solely pay for action. Table C1 shows the results. Columns (1) and (2) show evidence of pay for luck and action.

In Column (1), following Bertrand and Mullainathan (2001) we use market value of equity as our main performance variable, that is instrumented with market value of real estate in the first stage. We find a positive and significant coefficient, which is consistent with CEOs being payed for luck and potentially for action. In Column (2) we use real estate market prices as an instrument for stock returns. We find a positive and significant coefficient for stock returns which again can be interpreted as pay for luck. In Columns (3) and (4) we use real estate prices as an instrument for ROA. We find a positive and significant coefficient for ROA, which is consistent with pay for action, since as pointed out, ROA is not expected to correlate with real estate prices in the first stage unless the CEO responds to luck. Interestingly, when we instrument for accounting performance the coefficients on stock market performance are not significant, which casts 
doubts on the evidence of pay for luck. A potential limitation of this approach consists on the possible violation of the exclusion restriction, necessary for the validity of the instrumental variable approach. The idea being that $\mathrm{CEO}$ compensation can only be affected by changes in real estate prices through firm performance and not any other channel.

\section{Table C1. Bertrand and Mullainathan (2001) Pay for Luck and Pay for Action Estimates}

This table presents estimates of two stage panel regressions of the $\log$ (Total Compensation) on luck and responses to luck. The first stage regressions use HPI to predict firm performance as measured by MVE (Column 1), Stock Return (Column 2) and ROA (Columns 3 and 4). The second stage regressions include the predicted firm performance as measures of luck in the case of MVE and Stock Return (Columns 1 and 2) and action in the case of ROA (Columns 3 and 4). The sample consists of all firms in Execucomp and Compustat for which Real Estate Assets data and HPI data is available for the years 1992 - 2016 inclusive. HPI denotes CBSA-level house prices, as obtained from the Federal Housing Finance Association's (FHFA) database. All variables are winsorized at the $1^{\text {th }}$ and $99^{\text {th }}$ percentile values. Variables are defined in the Appendix A. Asterisks indicate statistical significance at the $1 \%\left({ }^{* * *}\right), 5 \%\left({ }^{* *}\right)$, or $10 \%\left({ }^{*}\right)$ level. Note: Since R-squared has no statistical meaning in the context of 2SLS/IV, we do not tabulate it.

\begin{tabular}{|c|c|c|c|c|}
\hline & (1) & (2) & (3) & (4) \\
\hline Log(MVE) & $\begin{array}{l}0.148^{* *} \\
{[2.209]}\end{array}$ & & $\begin{array}{c}0.005 \\
{[0.437]}\end{array}$ & \\
\hline ROA & & & $\begin{array}{l}0.279^{* *} \\
{[2.121]}\end{array}$ & $\begin{array}{l}0.347^{* *} \\
{[2.209]}\end{array}$ \\
\hline Stock Return & & $\begin{array}{c}0.194^{*} \\
{[1.924]}\end{array}$ & & $\begin{array}{c}-0.011 \\
{[-1.154]}\end{array}$ \\
\hline $\operatorname{ROA}(\mathrm{t}-1)$ & $\begin{array}{c}-0.042 \\
{[-1.315]}\end{array}$ & $\begin{array}{l}0.073^{* *} \\
{[2.446]}\end{array}$ & $\begin{array}{c}-0.013 \\
{[-0.661]}\end{array}$ & $\begin{array}{c}-0.022 \\
{[-0.736]}\end{array}$ \\
\hline Stock Return(t-1) & $\begin{array}{c}-0.004 \\
{[-0.554]}\end{array}$ & $\begin{array}{c}0.047^{* * *} \\
{[2.633]}\end{array}$ & $\begin{array}{c}0.005 \\
{[1.601]}\end{array}$ & $\begin{array}{c}0.001 \\
{[0.211]}\end{array}$ \\
\hline Log(Assets) & $\begin{array}{c}-0.090 \\
{[-1.437]}\end{array}$ & $\begin{array}{l}0.050^{* * *} \\
{[15.965]}\end{array}$ & $\begin{array}{c}0.037^{* * * *} \\
{[4.357]}\end{array}$ & $\begin{array}{l}0.040^{* * *} \\
{[10.330]}\end{array}$ \\
\hline Tobin's Q & $\begin{array}{c}-0.031 \\
{[-1.521]}\end{array}$ & $\begin{array}{c}-0.027 \\
{[-1.293]}\end{array}$ & $\begin{array}{c}0.009^{* * *} \\
{[3.227]}\end{array}$ & $\begin{array}{c}0.012^{* * *} \\
{[7.353]}\end{array}$ \\
\hline Volatility & $\begin{array}{l}1.040^{* *} \\
{[1.988]}\end{array}$ & $\begin{array}{l}-1.684^{* *} \\
{[-1.960]}\end{array}$ & $\begin{array}{l}0.240^{* *} \\
{[2.070]}\end{array}$ & $\begin{array}{c}0.361 \\
{[1.423]}\end{array}$ \\
\hline CEO Age & $\begin{array}{c}0.009^{* * * *} \\
{[3.264]}\end{array}$ & $\begin{array}{l}0.005^{* *} \\
{[2.354]}\end{array}$ & $\begin{array}{c}0.004^{* * *} \\
{[2.760]}\end{array}$ & $\begin{array}{c}0.004^{* * *} \\
{[2.603]}\end{array}$ \\
\hline CEO Age Squared & $\begin{array}{c}-0.000^{* * *} \\
{[-3.617]}\end{array}$ & $\begin{array}{c}-0.000^{* * *} \\
{[-2.871]}\end{array}$ & $\begin{array}{c}-0.000^{* * *} \\
{[-3.430]}\end{array}$ & $\begin{array}{c}-0.000^{* * *} \\
{[-3.277]}\end{array}$ \\
\hline Observations & 15,397 & 15,397 & 15,397 & 15,397 \\
\hline Firm FE & $\bar{Y}$ & $\bar{Y}$ & $\mathrm{Y}$ & $\bar{Y}$ \\
\hline Yr FE & $\mathrm{Y}$ & $\mathrm{Y}$ & Y & Y \\
\hline Cluster Firm & $\mathrm{Y}$ & $\mathrm{Y}$ & Y & $\mathrm{Y}$ \\
\hline
\end{tabular}




\section{Appendix D}

\section{Table D1. Pay for Action With a Minimum of Ten Observations per Firm}

This table replicates Table 3 in the paper and examines the role of responses to real estate luck in CEO compensation when we restrict our sample to firms that have more than 10 years of observations. Asterisks indicate statistical significance at the $1 \%\left(^{* * *}\right), 5 \%(* *)$, or $10 \%\left({ }^{*}\right)$ level.

\begin{tabular}{|c|c|c|c|c|c|c|c|}
\hline & (1) & (2) & (3) & (4) & (5) & (6) & (7) \\
\hline RE_Value & $\begin{array}{c}0.029^{*} \\
{[1.845]}\end{array}$ & $\begin{array}{c}0.030^{*} \\
{[1.932]}\end{array}$ & $\begin{array}{c}0.031^{*} \\
{[1.942]}\end{array}$ & $\begin{array}{l}0.032^{* *} \\
{[2.111]}\end{array}$ & $\begin{array}{l}0.031^{* *} \\
{[2.006]}\end{array}$ & $\begin{array}{l}0.042^{* *} \\
{[2.554]}\end{array}$ & $\begin{array}{l}0.042^{* *} \\
{[2.565]}\end{array}$ \\
\hline RE_Value $x$ ROA & $\begin{array}{l}0.100^{* *} \\
{[1.999]}\end{array}$ & & & & & & \\
\hline RE_Value x RE_Sales & & $\begin{array}{l}0.097^{* *} \\
{[2.176]}\end{array}$ & $\begin{array}{c}0.053^{* * *} \\
{[2.668]}\end{array}$ & & & & \\
\hline RE_Sales & & $\begin{array}{c}-0.054 \\
{[-0.868]}\end{array}$ & & & & & \\
\hline RE_Value x LT_Debt_Issues & & & & $\begin{array}{l}0.032^{* *} \\
{[2.041]}\end{array}$ & $\begin{array}{c}0.011 \\
{[1.009]}\end{array}$ & & \\
\hline LT_Debt_Issues & & & & $\begin{array}{c}-0.011 \\
{[-1.096]}\end{array}$ & & & \\
\hline RE_Value x SLB & & & & & & $\begin{array}{c}-0.037 \\
{[-0.972]}\end{array}$ & $\begin{array}{c}0.037^{*} \\
{[1.866]}\end{array}$ \\
\hline SLB & & & & & & $\begin{array}{c}0.045^{* * *} \\
{[2.860]}\end{array}$ & \\
\hline ROA & $\begin{array}{c}0.018^{*} \\
{[1.828]}\end{array}$ & $\begin{array}{c}0.033^{* * *} \\
{[4.160]}\end{array}$ & $\begin{array}{c}0.033^{* * *} \\
{[4.289]}\end{array}$ & $\begin{array}{c}0.032^{* * *} \\
{[4.458]}\end{array}$ & $\begin{array}{c}0.031^{* * *} \\
{[4.268]}\end{array}$ & $\begin{array}{c}0.029^{* * *} \\
{[2.973]}\end{array}$ & $\begin{array}{c}0.028^{* * *} \\
{[2.970]}\end{array}$ \\
\hline Stock Return & $\begin{array}{c}0.008^{* * *} \\
{[2.970]}\end{array}$ & $\begin{array}{c}0.008^{* * *} \\
{[3.043]}\end{array}$ & $\begin{array}{c}0.008^{* * *} \\
{[3.066]}\end{array}$ & $\begin{array}{c}0.008^{* * *} \\
{[2.940]}\end{array}$ & $\begin{array}{c}0.008^{* * *} \\
{[3.040]}\end{array}$ & $\begin{array}{l}0.008^{* *} \\
{[2.651]}\end{array}$ & $\begin{array}{l}0.008^{* *} \\
{[2.650]}\end{array}$ \\
\hline $\operatorname{ROA}(\mathrm{t}-1)$ & $\begin{array}{c}0.022^{* * *} \\
{[3.235]}\end{array}$ & $\begin{array}{c}0.022^{* * *} \\
{[3.082]}\end{array}$ & $\begin{array}{c}0.022^{* * *} \\
{[3.222]}\end{array}$ & $\begin{array}{l}0.020^{* *} \\
{[2.617]}\end{array}$ & $\begin{array}{c}0.022^{* * *} \\
{[3.287]}\end{array}$ & $\begin{array}{l}0.022^{* *} \\
{[2.307]}\end{array}$ & $\begin{array}{l}0.022^{* * *} \\
{[2.333]}\end{array}$ \\
\hline Stock Return(t-1) & $\begin{array}{c}0.014^{* * *} \\
{[6.824]}\end{array}$ & $\begin{array}{c}0.014^{* * *} \\
{[6.962]}\end{array}$ & $\begin{array}{c}0.014^{* * *} \\
{[6.974]}\end{array}$ & $\begin{array}{c}0.014^{* * *} \\
{[6.940]}\end{array}$ & $\begin{array}{c}0.014^{* * *} \\
{[7.003]}\end{array}$ & $\begin{array}{c}0.014^{* * *} \\
{[6.723]}\end{array}$ & $\begin{array}{c}0.014^{* * *} \\
{[6.667]}\end{array}$ \\
\hline Log(Assets) & $\begin{array}{l}0.043^{* * *} \\
{[12.155]}\end{array}$ & $\begin{array}{l}0.042^{* * *} \\
{[12.360]}\end{array}$ & $\begin{array}{l}0.042^{* * *} \\
{[12.302]}\end{array}$ & $\begin{array}{l}0.041^{* * *} \\
{[12.256]}\end{array}$ & $\begin{array}{l}0.042^{* * *} \\
{[11.606]}\end{array}$ & $\begin{array}{l}0.042^{* * *} \\
{[10.133]}\end{array}$ & $\begin{array}{l}0.042^{* * *} \\
{[10.090]}\end{array}$ \\
\hline $\operatorname{HPI}(\mathrm{t}-1)$ & $\begin{array}{c}-0.013^{*} \\
{[-1.827]}\end{array}$ & $\begin{array}{c}-0.012 \\
{[-1.715]}\end{array}$ & $\begin{array}{c}-0.012^{*} \\
{[-1.724]}\end{array}$ & $\begin{array}{l}-0.012^{*} \\
{[-1.721]}\end{array}$ & $\begin{array}{l}-0.012^{*} \\
{[-1.720]}\end{array}$ & $\begin{array}{l}-0.017^{* *} \\
{[-2.149]}\end{array}$ & $\begin{array}{l}-0.017^{* *} \\
{[-2.170]}\end{array}$ \\
\hline Tobin's Q & $\begin{array}{c}0.011^{* * *} \\
{[6.855]}\end{array}$ & $\begin{array}{c}0.011^{* * *} \\
{[7.021]}\end{array}$ & $\begin{array}{c}0.011^{* * *} \\
{[6.918]}\end{array}$ & $\begin{array}{c}0.011^{* * *} \\
{[6.993]}\end{array}$ & $\begin{array}{c}0.011^{* * *} \\
{[6.925]}\end{array}$ & $\begin{array}{c}0.011^{* * *} \\
{[5.744]}\end{array}$ & $\begin{array}{c}0.011^{* * *} \\
{[5.746]}\end{array}$ \\
\hline Volatility & $\begin{array}{c}-0.169 \\
{[-0.908]}\end{array}$ & $\begin{array}{c}-0.176 \\
{[-0.947]}\end{array}$ & $\begin{array}{c}-0.176 \\
{[-0.940]}\end{array}$ & $\begin{array}{c}-0.172 \\
{[-0.935]}\end{array}$ & $\begin{array}{c}-0.171 \\
{[-0.920]}\end{array}$ & $\begin{array}{c}-0.164 \\
{[-0.818]}\end{array}$ & $\begin{array}{c}-0.161 \\
{[-0.802]}\end{array}$ \\
\hline CEO Age & $\begin{array}{l}0.006^{* *} \\
{[2.086]}\end{array}$ & $\begin{array}{l}0.006^{* *} \\
{[2.216]}\end{array}$ & $\begin{array}{l}0.006^{* *} \\
{[2.175]}\end{array}$ & $\begin{array}{l}0.006^{* *} \\
{[2.097]}\end{array}$ & $\begin{array}{l}0.006^{* *} \\
{[2.188]}\end{array}$ & $\begin{array}{c}0.004 \\
{[1.354]}\end{array}$ & $\begin{array}{c}0.004 \\
{[1.365]}\end{array}$ \\
\hline CEO Age Squared & $\begin{array}{l}-0.000^{*} \\
{[-1.772]}\end{array}$ & $\begin{array}{l}-0.000^{*} \\
{[-1.889]}\end{array}$ & $\begin{array}{l}-0.000^{*} \\
{[-1.840]}\end{array}$ & $\begin{array}{l}-0.000^{*} \\
{[-1.761]}\end{array}$ & $\begin{array}{l}-0.000^{*} \\
{[-1.853]}\end{array}$ & $\begin{array}{c}0 \\
{[-1.003]}\end{array}$ & $\begin{array}{c}0 \\
{[-1.012]}\end{array}$ \\
\hline Observations & 12,231 & 12,231 & 12,231 & 12,169 & 12,231 & 9,708 & 9,708 \\
\hline R-squared & 0.828 & 0.828 & 0.828 & 0.829 & 0.828 & 0.818 & 0.818 \\
\hline Firm-CEO FE & Y & Y & Y & Y & Y & Y & Y \\
\hline Ind-Yr FE & $\mathrm{Y}$ & Y & $\mathrm{Y}$ & $\mathrm{Y}$ & $\mathrm{Y}$ & $\mathrm{Y}$ & $\mathrm{Y}$ \\
\hline Cluster MSA \& Year & $\mathrm{Y}$ & Y & Y & Y & Y & Y & Y \\
\hline
\end{tabular}




\section{E Appendix E}

\section{E.1 Event study: sale and leaseback transactions}

In Table E1, we perform an event study around SLB transaction announcement dates and find significant positive abnormal returns, suggesting that this specific CEO action, on average, creates value for shareholders. For these tests, we use the sample of SLB transactions from Whitby (2013). We find that SLB transactions in general generate significant cumulative abnormal returns (CAR) between 1.3\% and 1.4\%. When restricting the sample to SLBs of real estate assets only, CAR are between $2.1 \%$ and $2.3 \%$. As for SLBs that occur as responses to increases in real estate prices (meaning change in HPI $>0$ ), we find CAR between $1.9 \%$ and $2 \% .{ }^{27}$ These results are consistent with the idea that incentivizing managers to respond to real estate luck or paying them ex-post if the action is observable might be optimal.

\section{Table E1. Cumulative Abnormal Returns at the Announcement of Sale-and-Leasebacks}

The table presents the return effects associated with the announcement of a sale and leaseback transaction. The cumulative abnormal return (CAR) is calculated using the market model, which is estimated using the CRSP equally-weighted stock returns over the prior 252 days. Day 0 is the announcement date of the sale and leaseback (SLB). The sample consists of SLB transactions from 1980 - 2011 and is from Whitby (2013). Significance at the 1\%, 5\%, and 10\% level is denoted by ${ }^{* * *}, * *$, and ${ }^{*}$, respectively.

\begin{tabular}{rccc}
\hline \multicolumn{5}{c}{ Full Sample of Sale-Leasebacks $(\mathbf{N}=\mathbf{3 5 8})$} \\
& Mean & Pos/Neg & Patell Z \\
\hline CAR $(-1,1)$ & 0.0127 & $194 / 164$ & $4.183^{* * *}$ \\
CAR $(-2,2)$ & 0.0134 & $192 / 166$ & $3.583^{* * *}$ \\
CAR $(-3,3)$ & 0.0137 & $192 / 166$ & $3.382^{* * *}$ \\
\hline \multicolumn{4}{c}{ Sale-Leasebacks of Real Estate only $(\mathbf{N}=\mathbf{2 0 6})$} \\
Mean & Pos/Neg & Patell Z \\
\hline CAR $(-1,1)$ & 0.0205 & $115 / 91$ & $4.349^{* * *}$ \\
CAR $(-2,2)$ & 0.0229 & $117 / 89$ & $3.744^{* * *}$ \\
CAR $(-3,3)$ & 0.0216 & $111 / 95$ & $3.153^{* * *}$ \\
\hline \multicolumn{5}{c}{ Sale-Leasebacks of Headquarters only $\mathbf{N}=\mathbf{6 9 )}$} \\
\multicolumn{5}{c}{ Mean } & Pos/Neg & Patell Z \\
\hline CAR $(-1,1)$ & 0.0094 & $39 / 30$ & $1.895^{* *}$ \\
CAR $(-2,2)$ & 0.0112 & $44 / 25$ & $2.019^{* *}$ \\
CAR $(-3,3)$ & 0.0019 & $40 / 29$ & 1.272 \\
\hline Sale-Leasebacks following Positive Real Estate Shocks $(\mathbf{N}=\mathbf{2 4 0})$ \\
\multicolumn{5}{c}{ Mean } & Pos/Neg & Patell Z \\
\hline CAR $(-1,1)$ & 0.0185 & $127 / 113$ & $3.525^{* * *}$ \\
CAR $(-2,2)$ & 0.0204 & $126 / 114$ & $2.777^{* * *}$ \\
CAR $(-3,3)$ & 0.0187 & $122 / 118$ & $2.519^{* * *}$ \\
\hline
\end{tabular}

\footnotetext{
${ }^{27}$ In additional (untabulated) analysis, we test the CAR around SLBs following positive real estate shocks relative to CAR around SLBs following negative real estate shocks and obtain similar results as the CAR around SLBs following negative real estate shocks are indistinguishable from zero. This suggests that not only are the CAR around SLBs following positive real estate shocks significantly different from zero, but they are also significantly different from the CAR around SLBs following negative real estate shocks. We thank one of the reviewers for this suggestion.
} 


\section{F Appendix F}

\section{Table F1. First-Stage Results}

This table shows results of the first stage regression of the IV specification shown in Section 5.4. The dependent variables are: $H P I_{m, t}$, the growth in CBSA/MSA level real estate prices from 1993 to year $\mathrm{t}$, and $R E_{-} V_{a l u e_{i, t}}$, defined as the market value of a firm's real estate assets in year $t$. The instrument in the first-stage regression is land supply inelasticity interacted with the growth in aggregate U.S. real estate prices from 1992 to year $t$, as measured by the SP/Case-Shiller U.S. National Home Price Index, and $R E_{-} V a l u e_{i, 1992}$, a measure of the market value of a firm's real estate assets in 1992. As in Equation 1, we include firm and CEO-specific controls as defined in Section 3, and we include firm-CEO fixed effects, $\gamma_{i, c}$ and industry-year fixed effects, $\delta_{j, t}$. We further include interactions between firms' initial characteristics and the HPI: in particular, we include five quintiles of firm age, firm size, and ROA as well as two-digit SIC-industry and MSA dummies. Standard errors are clustered at the MSA and year level.

\begin{tabular}{lcc}
\hline & $\begin{array}{c}\text { RE_Value } \\
(1)\end{array}$ & $\begin{array}{c}\text { HPI } \\
(2)\end{array}$ \\
\hline & & \\
RE_Value $_{92}$ x Case-Shiller Index x Inelasticity & $0.008^{* * *}$ & -0.000 \\
& {$[8.064]$} & {$[-0.179]$} \\
Case-Shiller Index x Inelasticity & $-0.001^{* * *}$ & $0.007^{* * *}$ \\
& {$[-2.924]$} & {$[4.959]$} \\
& & \\
Observations & 12,364 & 12,364 \\
R-squared & 0.992 & 0.973 \\
& & \\
\hline Controls & $\mathrm{Y}$ & $\mathrm{Y}$ \\
Firm-CEO FE & $\mathrm{Y}$ & $\mathrm{Y}$ \\
Ind-Yr FE & $\mathrm{Y}$ & $\mathrm{Y}$ \\
Cluster MSA \& Year & $\mathrm{Y}$ & $\mathrm{Y}$ \\
\hline
\end{tabular}




\section{G Appendix G}

\section{Table G1. Types of News}

This table examines a series of sensitivity analyses with respect to the extent and type of real estate changes, following Balakrishnan et al. (2014), for sale and leaseback transactions (SLB). All specifications include all control variables used in Table 3, but for brevity, their coefficients are suppressed (Controls include: Stock Return(t), Log(Assets), predicted HPI(t-1) from the first stage, Tobin's Q, Volatility, ROA(t-1), Stock Return ( $t-1)$, CEO Age, CEO Age Squared). All variables are winsorized at the $1^{\text {th }}$ and $99^{\text {th }}$ percentile values. Remaining control variables are defined in the Appendix A. Asterisks indicate statistical significance at the $1 \%\left(^{* *}\right), 5 \%\left({ }^{* *}\right)$, or $10 \%\left({ }^{*}\right)$ level.

\begin{tabular}{lccc}
\hline & $(1)$ & $(2)$ & $(3)$ \\
\hline & CHG HPI Above Median & CHG HPI Below Median & CHG HPI Top Quartile \\
\cline { 2 - 4 } RE_Value & 0.049 & 0.038 & 0.056 \\
RE_Value x SLB & {$[1.555]$} & {$[1.094]$} & {$[1.359]$} \\
& $0.047^{*}$ & -0.103 & $0.195^{*}$ \\
Observations & {$[1.771]$} & {$[-1.476]$} & {$[1.920]$} \\
R-squared & & & 2,379 \\
& 5,635 & 5490 & 0.830 \\
\hline Other Controls & 0.824 & 0.869 & \\
Firm-CEO FE & & & $\mathrm{Y}$ \\
Ind-Yr FE & $\mathrm{Y}$ & $\mathrm{Y}$ & $\mathrm{Y}$ \\
Cluster MSA \& Year & $\mathrm{Y}$ & $\mathrm{Y}$ & $\mathrm{Y}$ \\
\hline
\end{tabular}

